\title{
The Utilization of Tree Bark
}

\author{
Zoltan Pásztory, ${ }^{\mathrm{a}, *}$ Ildikó Ronyecz Mohácsiné, ${ }^{\mathrm{a}}$ Galina Gorbacheva, ${ }^{\mathrm{b}}$ and \\ Zoltán Börcsök ${ }^{a}$
}

\begin{abstract}
The utilization of natural raw materials has been practiced for centuries. Of raw materials, wood and its bark have outstanding significance because of their special chemical components and unusual structure. Annual bark production is estimated to be between 300 and 400 million $\mathrm{m}^{3}$. The bark of different tree species has been used extensively in or in conjunction with modern technologies. This article presents a comprehensive summary of these methods of utilization and their results. The diversity of bark utilization derives from the variety of the bark of different species and from the possibilities encoded in the material. Following the anatomic summary, the protective role of the bark is discussed, highlighting its physical-chemical properties and the different methods of medical, energetic, and industrial utilization.
\end{abstract}

Keywords: Tree bark; Bark utilization

Contact information: a: University of West Hungary, Innovation Center, 4. Bajcsy Zs. Sopron 9400 Hungary; b: Department of Wood Science and Technology, Moscow State Forest University, $1^{\text {st }}$ Institutskaya Street, 1, Mytischi, Moscow region, 141005, Russia;

*Corresponding author: pasztory.zoltan@nyme.hu

\section{INTRODUCTION}

Tree cultivation is one of the main objectives of forestry; large amounts of renewable raw material are produced annually. A significant impact of tree cultivation is that it binds the carbon dioxide content of the air, and the carbon builds into the tree cell structure through photosynthesis. The amount of lumbered roundwood worldwide is estimated at 3,591,142,000 $\mathrm{m}^{3}$ (FAO 2015). Therefore, the annual global amount of bark, using a $10 \%$ bark ratio, is approximately $359,114,200 \mathrm{~m}^{3}$. In the middle of the $20^{\text {th }}$ century, an enormous and problematic amount of bark produced during lumbering and processing was most often delivered to dumps (Weissmann 1976). Bark produced in Californian sawmills alone is estimated to total between 2.2 and 2.6 million tonnes (Yang and Jenkins 2008). According to Feng et al. (2013), in Canada more than 17 million $\mathrm{m}^{3}$ of bark is produced yearly, and more than half of it is burned or delivered to dumps. The amount of bark removed from lumbered wood in Hungary reaches 500 to 600 thousand $\mathrm{m}^{3}$ (Molnár 2004), and, in Russia, approximately 30 million $\mathrm{m}^{3}$ yearly (Ushanova 2012; Melekhov et al. 2015). Quantifying the exact amount of bark produced annually is a complicated problem; despite strenuous efforts, its quantification involves considerable uncertainty, as only a small proportion of bark is traded.

Bark has numerous functions during the lifespan of the plant, while it also changes with age. The outer bark is very diverse and can take shapes characteristic to some species. Its thickness depends on the species, the age of the plant, and ecological factors, and it can even vary in different parts of the tree (Fekete 1951; Gencsi 1980). For example, sclereids, 
which develop in the outer bark and make their structure rigid and hard, are found in many species (Butterfield et al. 1997).

The bark content of a tree can vary between 5 and 28\% (Nyikosov 1985; Sopp and Kolozs 2000; Molnár 2004; Guidi et al. 2008). Some broad-leafed species have an extremely high bark ratio, such as oak, poplar, and black locust. Guidi et al. (2008) examined the bark ratio of Populus deltoides L. clones at different ages because the bark ratio of the dendromass directly affects the quality and economic value. By decreasing the diameter, the bark ratio also decreased to approximately $4 \mathrm{~cm}$, where it stabilized.

\section{BARK ANATOMY}

The primary plant stem is covered with epidermis. Its cells have thin walls, tightly fit next to each other, and their external face is covered with a considerable amount of wax (Haraszty 1988; Gyurján 1996). Ligneous plants live for years, growing continually during their life span. This growth is accompanied by the thickening of the stems. The epidermis can keep pace with the thickening of the stem for only a short time, after which it splits open (Martin and Crist 1970; Fodor 2004). The cortex, which is rich in intercellular channels, splits open as well. This damage to the epidermis is harmful, as the deeper tissues can be susceptible to infections, and the plant risks withering due to evaporation.

For this reason, a line of cells in the inner parts of the cortex reproduces by fission and creates new epidermis. This secondary meristem is called the phelloderm. These cells have thin walls and are large in size. Usually they reproduce with walls parallel to the surface, creating phellom outwards and phelloderm inwards. The cells of the phellom necrose quickly after evolving, while suberin is sedimented in the cell walls in a process called suberification.

As a result of incrustation, the cell walls become totally impermeable to water and almost impermeable to gases. The cells of the phelloderm are similar to the cortex, containing plasma, having relatively thin walls, and are similar to parenchyma. The phellogen develops more deeply each year in the stems of the long-living ligneous plants. Although the phellogen creates phelloderm cells inwards, it creates more cell lines outwards. Therefore, the parenchyma-like cells of the bark are used up (Ghosh 2006).

Over time, the cambium, which is responsible for the cross-section growth of the plant stem, develops phloem rings. By thinning the cortex, the phellogen gets closer to the most external layer, i.e., the earliest phloem ring. When the cortex is used up, the next year the formation of the phellogen enters the phloem, forming from the living cells or phloem parenchyma found there. From that point forward, the external tissue consists of the phellom cells developed by the phellogen, as well as particles of the phloem such as phloem fiber, sieve tubes, and sieve cells.

The tissue that characteristically splits and develops in this way, thickening over time, is called rhytidome. The most external layers can break off from the surface in the form of bark plates. The most important tasks of the rhytidome are to protect the sprout from mechanical damage and external impacts, to prevent water loss, and to reduce frost effects (Oskolski and Van Wyk 2010). Some metabolic products, such as tannic acid, can accumulate in the bark. 


\section{PROTECTIVE ROLE OF BARK}

Tree bark shelters dozens of organisms; it is the habitat of different arthropoda, vertebrata, lichen, moss, and other living creatures. Most entities do not "damage" the environment in which they live, but there are some species that damage trees, e.g., woodborers or bark beetles. In pines (Pinus), the resin flow in the bark has a significant role in the protection against woodborers (Popp et al. 1991).

The bark protects the tree from weather conditions, insect pests, and browsing, and it also has crucial role in the case of wood fires. Much research has been conducted on this subject. Schafer et al. (2015), Catry et al. (2010), Lawes et al. (2011), Wang and Wangen (2011), do Vale and Elias (2014), Dickinson and Johnson (2001), and Dickinson (2002) established that the relative thickness of the bark significantly influences the survival of trees in a fire. Bauer et al. (2010) examined the probability of survival for a tree if its surface is exposed to fire. They found that the fire resistance of the bark depends on thickness and moisture content and that the different physical qualities of tree species have a negligible influencing role. Hengst and Dawson (1993) had similar results.

\section{BARK AS A POLLUTION INDICATOR}

Using bark as a bioindicator is advantageous because bark is always exposed to air pollution. It has a large surface area for contact with air, and its structure and porosity (e.g., crackings, knobs) aids in preserving pollution longer than on the surface of leaves, where rain can easily wash it off (Härtel 1982; Kuik and Wolterbeek 1994; Böhm et al. 1998; Saarela et al. 2005; Mandiwana et al. 2006). Pollution is found by examining bark even if there are no pollutants in the air. Grodzinska used the growth of acidity in tree barks to estimate the quantity of pollution in Poland $(1971 ; 1978 ; 1979 ; 1982)$, and more studies dealt with the connection of air pollution and bark acidity (Staxäng 1969; O'Hare 1974; Świeboda and Kalemba 1979; Santamaría and Martin 1997; Kuang et al. 2006; Marmor and Randlane 2007; Steindor et al. 2011). Lötschert (1983) drew a pollution map of the city of Frankfurt by examining the bark of different species. Saarela et al. (2005) performed analysis in connection with contamination of the bark and wood of pine species (Pinus) in the western part of Finland. They found that heavy metal content in samples from contaminated areas near factories was higher. Berlizov et al. (2007) used bark of the black poplar (Populus nigra) to reveal different metal pollutants. Sawidis et al. (2011) used the bark of Pinus nigra and Platanus orientalis as bioindicators to demonstrate air pollution in cities. Other species such as oak (Quercus sp.), elm (Ulmus sp.), willow (Salix sp.), poplar (Populus sp.), ash (Fraxinus sp.), maple (Acer sp.), linden (Tilia sp.), pine (Pinus sp.), yew (Taxus baccata), locust (Robinia pseudoacacia L.), olive tree (Olea europaea), cedar (Cedrus atlantica), cyprus (Cupressus sempervirens), eucalyptus species (Eucalyptus sp.), and others were also used to demonstrate the presence of metal and other pollutants (Barnes et al. 1976; Fatoki and Ayodele 1991; Lippo et al. 1995; Poikolainen 1997; Schulz et al. 2000a, 2000b; El-Hasan et al. 2002; Mandiwana et al. 2006; Gemici et al. 2006; Kuang et al. 2006; Suzuki 2006; Berlizov et al. 2007; Li et al. 2008; Steindor et al. 2011). Bark preserves the pollutants of the past so that, with the help of bark ingrowths formed due to damage, conclusions can be drawn from small samples for a historical perspective on the intensity and source of lead pollution (Satake et al. 1996; Bellis et al. 2002a, 2002b; Wang et al. 2003; Åberga et al. 2004; Conkova and Kubiznakova 2008). 


\section{PHYSICAL AND CHEMICAL CHARACTERIZATION OF BARK}

\section{Moisture Content}

The moisture content of bark can vary widely, and it is influenced by several factors such as the species of tree, manner of storage (wet or dry), season, method of debarking, and whether the removed bark was hit by rainfall (Corder 1976). The moisture content of the inner bark/phloem is usually 7 to 10 times greater than that of the outer bark. Therefore, the average moisture of the bark is primarily influenced by the quantitative proportion of the inner and outer bark. Immediately after lumbering, the average net moisture content of the bark is very high, e.g., $120 \%, 112 \%, 127 \%, 58 \%$ to more than $150 \%$ in Scotch pine, spruce, beech, and birch, respectively (Corder 1976; Clark et al. 1985; Ugolev 1986; Dibdiakova et al. 2014). During wood yard storage, the outer bark of most species loses its moisture content relatively quickly. Until the bark removal at sawmills, the average net moisture content of the scaly bark spruce and Scotch pine is reduced to 60 to $70 \%$, while that of the ring shake bark of birch practically does not change (Ugolev 1986). The mass calculated heating value of the bark is practically the same as the wood, 17 to $25 \mathrm{MJ} / \mathrm{kg}$ (Corder 1976; Németh and Molnár 1983), but, for example, the birch outer bark is $35 \mathrm{MJ} / \mathrm{kg}$ (Ugolev 1986; Hakkila 1989).

From the point of view of heating technology, fuel volume must be taken into consideration. According to the research of Németh and Molnár (1983), the characteristics of bark were significantly less favorable, e.g., the heating value of absolute dry locust wood was $13.526 \mathrm{MJ} / \mathrm{m}^{3}$, and that of the bark was $4.983 \mathrm{MJ} / \mathrm{m}^{3}$. Şen et al. (2010) examined the organic compounds of the bark and phloem of Quercus cerris. These authors noted that the separation of the bark and phloem would be prerequisite for utilization of the bark, as their compounds are different; phloem has a much higher moisture content.

\section{Density}

The density of the bark in air-dried conditions varies, for example, oak (pedunculate, sessile) with $480 \mathrm{~kg} / \mathrm{m}^{3}$, aspen with $590 \mathrm{~kg} / \mathrm{m}^{3}$, and Scotch pine with 370 $\mathrm{kg} / \mathrm{m}^{3}$ (Polubojarinov 1976). For 156 North American wood species, Miles and Smith (2009) measured average values of 400 to $500 \mathrm{~kg} / \mathrm{m}^{3}$. For some oak species, the density reached $750 \mathrm{~kg} / \mathrm{m}^{3}$, but in some pines (Pinus), the value remained under $300 \mathrm{~kg} / \mathrm{m}^{3}$. Certainly density and specific gravity were influenced by several factors, e.g., age and geographical position (Patrick et al. 2009).

\section{Chemical Compounds}

In elemental analyses, bark differs from the wood only in ash components.

Table 1. Chemical Compounds of Spruce Wood and Bark (Ugolev 1986)

\begin{tabular}{|c|c|c|c|c|}
\hline & Carbon (\%) & Hydrogen (\%) & Oxygen (\%) & Other Elements (\%) \\
\hline Wood & 50.0 & 6.0 & 43.5 & 0.5 \\
\hline Inner bark & 51.5 & 5.7 & 38.8 & 4.0 \\
\hline Outer bark & 44.4 & 6.4 & 45.4 & 3.8 \\
\hline
\end{tabular}

The phloem and the outer bark are much richer in minerals than the wood. Values significantly differ between wood species, such that dry mass values are between 1.5 and 10.0\% (Chang and Mitchell 1955; Millkin 1955; Corder 1976; Zhitkov 1985; Szendrey 
1986; Han and Shin 2014; Deineko and Faustova 2015); usually less ash content is measured in gymnosperms (Naunes et al. 1999). Al, Mn, Mo, Ca, P, Mg, Zn, Cu, Fe, B, N, $\mathrm{K}, \mathrm{Ni}, \mathrm{Cr}, \mathrm{Pb}, \mathrm{Si}$, and $\mathrm{Na}$ are present in ash, but usually $\mathrm{Ca}, \mathrm{N}$, and $\mathrm{K}$ are dominant (Young 1971; Lambert 1981; Ragland and Aerts 1991; Olander and Steenari 1995; Piotrowska et al. 2012; Miranda et al. 2012; Wang and Dibdiakova 2014). Millkin (1955) defined the main elements in numerous species, showing that gymnosperms have over $50 \%$ carbon content. For angiosperms, the standard deviation was a bit bigger, with occasional values under 50\%. Barboutis and Lykidis (2014) calculated higher ash content in gymnosperms. Shin and Han compared the bark and wood of Salix caprea (2014). The ash content of the bark was between 3.8 and $4.7 \%$, while the wood had between 0.6 and $1.1 \%$. Polysaccharide content was higher in wood (62.8 to $70.6 \%)$ than in bark (44.1 to $47.6 \%)$. The main monosaccharides creating hemicellulose in wood are xylose, and in the bark, xylose, arabinose, and galactose.

\section{Organic Compounds}

The organic compound content of phloem and outer bark is characterized by a relatively low amount of cellulose. While wood contains 40 to $50 \%$ cellulose and the phloem contains 18 to $25 \%$, the outer bark contains only 3 to $17 \%$ (Ugolev 1986). However, other experiments that examined the entire bark did not show such a drastic difference (Harkin and Rowe 1971; Usta and Kara 1997; Melin 2008; Dibdiakova et al. 2014).

The other main component of bark is lignin (Naunes et al. 1999; Fradinho et al. 2002; Jové et al. 2011; Miranda et al. 2012; Feng et al. 2013). Deineko and Faustova (2015) showed that, in aspen, lignin in the outer bark had a concentration of over $20 \%$.

Suberin is essential to suberification (Cordeiro et al. 1998; Gandini et al. 2006; Jové et al. 2011; Sudakova et al. 2012; Miranda et al. 2013). Coquet et al. (2008) tried to identify suberin monomers, finding 3-friedelanol, 2,6-heptanediol, friedelin, and betulin. Graça and Santos (2006a, 2006b) concluded that cork suberin is a glycerol-containing lipid, the main monomers are glycerol, long-chain $\alpha, \omega$-diacids and $\omega$-hydroxyacids, and the molecule size of the suberin is similar to other biopolymers. Other research supported these objectives, so it is now said that the suberin is a polyester type macromolecule and the major component of it are long-chain aliphatic acids, representing typically 80 to $90 \%$ in mass of all monomers, and the quantity of the glycerol in suberins is relatively low. The main characteristic of suberin acids is that they are $\alpha, \omega$-bifunctional. Two main groups of fatty acids are found in suberin: the $\alpha, \omega$-diacids and the $\omega$-hydroxyacids (carboxylic acid in the $\alpha$ position and a hydroxyl group in the $\omega$ position). The chain length of both of them range typically from $\mathrm{C}_{16}$ to $\mathrm{C}_{26}$. When suberin is depolymerized, phenolic compounds are also found; ferulic acid is always present and aminated phenolics namely tyramine has also been found (Pollard et al. 2008; Beisson et al. 2012; Graça 2015). Jové et al. (2011) examined the bark of Quercus suber. Suberin and lignin were the two major components; holocellulose, extractives, and ash content amounts changed due to their location and the position of the sample in the bark.

In a study of extractable phenolic compounds in the cork of Quercus suber, Fernandes et al. (2011) identified 33 compounds, mostly gallic acid derivatives and gallotannins, ellagitannins, and ellagic acid derivatives. Other compounds were low molecular weight phenolic acids and aldehydes. Sudakova et al. (2012) showed that the treatment of outer birch-bark by water alkali partially hydrolyzes the suberin component, while the hydrolysis by alcohol alkali leads to the formation of suberinic acid mixtures. 


\section{ADDITIONAL MATERIALS}

Additional materials and secondary metabolic products are present in the bark in relatively high quantities (up to 20\%) and are often characteristic of a family or genus. In particular, the presence of tannin is characteristic. Previously, oak, spruce, willow, and chestnut bark were used to produce tannic acid because their tannic acid content exceeded that of wood. Extracting tannin was made by drying, grinding, soaking, and cooking. The furs previously depilated and soaked in lime liquor were put into the extracted reddishbrown fluid (Portik 2006). The liquors of freshly separated phloem contained fermentable sugars such as glucose, fructose, and mannose (Szendrey 1986).

Abyshev et al. (2007) examined the extract of Betula pubescens bark, finding the following compound groups: terpenoids $(75.2 \%)$, the esters of these terpenoids $(4.7 \%)$, ether oils $(0.08 \%)$, hydrocarbons $(6.3 \%)$, the epoxides of those hydrocarbons $(1 \%)$, steroids ( $\beta$-sitosterol $2.7 \%)$, tannins $(2.1 \%)$, flavonoids $(1.56 \%)$, hydroxycoumarins $(0.85 \%)$, and several unidentified compounds (approximately 4\%). Narasimhachari and von Rudloff (1961) isolated thujopsene, 1-cedren, cuparetle, cedrol, widdrol, 8-sitosterol, esters of fatty acids, $\beta$-sitosterol, lignan savinin, and diterpene communic acid from Juniperus horizontalis. With the help of these experiments, they developed a preparative technology for the highly productive subtraction of betulinol and its derivatives, which went under pharmacologic examinations. Vázquez et al. (2008) examined the total phenol content of the bark of Eucalyptus globulus that was industrial waste for antioxidant activity. The bark extract of eucalyptus contains materials with lower molecular mass. Of the non-cellulose monosaccharides, arabinose, xylose, and mannose were found in higher amounts (Miranda et al. 2013).

Naunes et al. (1999) found significant polysaccharide content in Pinus pinea (36.8\%), with a monosaccharide content as follows: glucose (44.6\%), mannose (18.2\%), xylose $(20.7 \%)$, galactose $(7.6 \%)$, and arabinose (8.9\%). Fradinho et al. (2002) examined Pinus pinaster and found that the condensed tannins were mainly composed of catechintype structural units. Rowe et al. (1969) isolated natural trans- and cis-pinosylvin dimethyl ether (3.5-dimetoxi-cis-stilben) from the bark of Pinus bunksiuna. Moreover, they could also isolate wax alcohol esters of ferulic acid dehydroabietic acid and their deterpenes and phlobatannin esters. According to Feng et al. (2013), the bark contains a large amount of extractives and lignin (50\% of dry mass) that can be a renewable source of chemical compounds, especially aromatic compounds. Thalhamer and Himmelsbach (2014) derived quillaja-saponins from the bark of Quillaja saponaria (L). Lin et al. (2013) demonstrated dibenz perilen derivatives from the bark of Juglans mandshurica, which is important in chemotaxonomy.

Spruce (Picea abies) is an important raw material for forestry in Scandinavian countries (Kemppainen et al. 2014). For industrial use, condensed tannins have been extracted from spruce bark via hot water treatment. Kemppainen et al. established that spruce bark is a promising new source of tannins. However, because of its high sugar content, the raw extract must be treated before use. Le Normand et al. (2014) used hot water treatment to extract Picea abies bark carbohydrates, which stimulated the macrophages of the immune system. Grigorjuk et al. (2010) developed a method for processing conifer bark. After the extraction of lipids and polyphenols, the remaining bark was exposed to hydrolysis-extraction with acidified water for depositing a fraction of pectine substances. The bark of cork-oak was examined in further studies. Castola et al. (2002) identified betulinic acid sitosterol and sitost-4-en-3-on in samples of Quercus suber, 
which originated in different locations. Santos et al. (2010) examined Quercus suber cork and identified 15 phenolic components, e.g., ellagic acid, gallic acid, protocatechuic acid, salicylic acid, eriodictyol, naringenin, quinic acid, and hydroxyphenyllactic acid. The significant antioxidant activity of the samples have potential medical uses. Pinto et al. (2009) found hydroxyl fatty acid derivatives in cork and Betula pendula bark.

Kuznetsov et al. (2015) considered new ways of extracting valuable compounds from the bark of hardwoods and softwoods native to Siberia.

\section{DEBARKING METHODS}

The method for processing bark is determined by its origin, amount, moisture content, composition, form, and size. The phloem content and the moisture content of the bark, which fluctuates depending on the time of lumbering and the circumstances of its storage, affects the chosen applied technology. Chipping usually occurs in special machines suitable for processing round wood and other wood waste (Szalay 1981). There are different debarking technologies, including the rosser-head debarker, hammer-type debarker, ring debarker, drum debarker, water jet, and high frequency debarker (Hargitai 2003; Baroth 2005; Ressel 2006). To chop $1 \mathrm{~m}^{3}$ bark, approximately 5 to $20 \mathrm{kWh}$ electric energy is needed, depending on the bark characteristics (Hargitai 2003). Debarking is influenced by several factors. First, the wood species and the dimensions of the log block, the presence of the phloem fibers and sclereids, the tenacity of the bark, and, especially, the moisture content of the wood, which influences the strength of the bond between the bark and the wood (Einspahr et al. 1984; Chow and Obermajer 2004). The storage conditions are not negligible, and, in the case of high moisture content, temperature also has influence (Baroth 2005).

\section{POSSIBLE UTILIZATION OF BARK}

In ancient times, the utilization of bark was as natural as using other parts of the wood. For example, the soaked elm bark (Ulmus sp.) is good for calves to eat, and its fibrous quality was good for spinning ropes and making clothes. In Norway during the famine of 1812, bark was eaten and given as wedding presents (Richens 1983; Coleman 1998). The bark of different Pinus species was used as nourishment in winter in Scandinavia (Östlund et al. 2009). The significant differences among the barks of different species determine their use (Zhitkov 1985; Ushanova 2012).

\section{UTILIZATION AS MEDICINE}

The first medicines were supplied by plants. Their active ingredients, such as alkaloids, essential oils, carbohydrates, vitamins, and antibiotics, are the elements of the live unit mass of forests. Folk medicine used bark preparations of locust, willow, elm, oak, and ash to cure diseases (Rápóti and Romváry 1997). More species are used in perfume making as a material giving or fixing fragrance. In pharmacology, plant ingredients act as components of plasters, ointments, rubs, hair fluids, and other mixtures. The bark of several species has been used as medicine, in Europe, e.g., the condensed water extract of the bark 
or leaf of Chondrodendron tomentosum is curare, which is used in operations to hinder the smooth muscles. The bark of Cinchona pubescens gives quinine, which was long-used as the only medicine for malaria (Poyraz and Mat 2014). The bark of Frangula alnus is antiviral, antifungal, and a laxative. The decoction of Quercus robur and Q. petraea is used to cure inflammations of the skin and the mucous membrane. The bark of Cinnamomum cassia is not only a spice, but also has antibacterial and antifungal effects; moreover, it encourages appetite (Annegowda et al. 2012). The bark of Salix alba and S. fragilis are excellent painkillers and febrifuges. The bark of Aesculus hippocastanum can be used in cases of diarrhea, hemorrhoids, and skin problems (Tóth 2005). The bark and leaf of the African Warburgia salutaris is traditionally used to cure cold symptoms and coughs (Kotina et al. 2014). The brew of the bark of Robinia pseudoacacia is locally used to treat hyperacidity, constipation, and stomach and intestinal ulcers (Rabóti et al. 1997). Magnolia bark is traditionally used in Chinese and Japanese medicines (Liu et al. 2007). Tea tree bark is popularly used against diabetes in Brazil. The water stem extract lowers the bloodsugar level, increasing metabolism (Vasconcelos et al. 2011).

The Byrsonima intermedia species, indigenous to Brazil, has long been used against bleeding and diarrhea and as an antiphlogistic (Orlandi et al. 2011). The bark of the Brazilian Cariniara rubra is used to cure inflammation (Edson et al. 2011; Santos et al. 2011). In sub-Saharan Africa, the bark of the stem of Garcinia buchananii is used as a medicine against diarrhea, such as that caused by lactose (Boakye et al. 2012). In the bark of Acacia mangium, phenolic compounds are present in high concentration. These compounds contain many antioxidants that are beneficial to the human body, and they are used in cosmetic and pharmaceutical products (Zhang et al. 2010). The extract made from the bark of African sour cherry growing in Cameroon and Madagascar is excellent medicine to prevent prostate troubles afflicting elderly men (Szodfridt 2003). Teas of plants containing tannic acid are internally used against gastric hemorrhage, enteritis, gastric influenza and to stop diarrhea. They are externally used to paint gums, for throat rinses, as a compress on frozen or inflamed body parts, to stop sweating, and to bathe hemorrhoids (Rábóti et al. 1997).

Orlovskaya et al. (2013) studied the effect of the aqueous extract from the bark of Tilia cordata on the tone of smooth muscles of the intestinal intact and modeling acetylcholine spasm. According to Kiran and Chadrakant (2009), the terpenoid, flavonoid, alkaloid, saponin, and tannin content of the Careya arborea bark has liver protective and in vivo antioxidant qualities. According to Terangpi et al. (2013), the bark of Acacia pennata is traditionally used during the fermentation of rice. The African Sclerocarya birrea bark is traditionally used against dysentery, diarrhea, and other infectious diseases (Sarkar et al. 2014). Their study supported the effectiveness of the plant. Ponomarenko et al. (2014) found that the two types of non-cyclic diarylheptanoid isolated from the bark of Alnus incana were more effective as antioxidants than the curcumin used as reference.

Navid et al. (2014) examined the antiviral characteristics of penta-cyclic triterpenes (betulin, lupeol, and betulinic acid) of the bark of Betula pendula and found that they have high-level antiviral activity against certain herpes viruses. Comandini et al. (2014) isolated seven compounds from the bark of Castanea sativa (vescalin, castalin, gallic acid, vescalagin, 1-O-galloyl, castalagin, and ellagic acid). Their method gave information about the composition and quality of the chestnut bark samples, which are traded in dietary supplements. Jyske et al. (2014) examined bioactive stilbene-glucosides (astringin, isorhapontin, and picein) in Picea abies; the total output of compounds depends on the amount of the bark biomass and positively correlates with the volume of the whole tree and 
the bark. The lower part of the trunk was the most valuable stilbene source in both younger and older trees.

The bark of the ligneous shrub Acanthopanax sessiliflorus is traditionally thought to have an anticancer effect. Venkatesan et al. (2015) demonstrated the effectiveness of this bark extract on human breast cancer cells. The antibacterial effect of Quercus ilex bark depended on the circumstances of extraction and on the solvent, but more methods were proved to be effective (Berahou et al. 2007). Diouf et al. (2009) found antioxidant and antiphlogistic compounds in Picea mariana bark. Kim et al. (2015) examined the effect of essential oils of cinnamon bark, finding that some components effectively hinder the formation of the biofilm Pseudomonas aeruginosa, and other components reduce swarming bacteria and hemolytic activity. Grace et al. (2003) listed 174 African ligneous species that are used in native medicine. The subject of a patent invention is a liqueur with a special taste containing herbal and spice extracts and its production. The invention contains 1 to $2 \%$ quinine bark (Zsindelyes Kereskedőház Kft. 2011).

\section{ENERGETIC UTILIZATION}

Because of the shortage of raw materials, the exploration of alternative fuels is increasingly necessary. The burning of bark has been presented as a source of energy. Its energetic utilization is mostly influenced by the fact that the ash content of the bark is much higher than that of wood. Real possibilities are hidden in European forests, and the energetic utilization of wood will grow in the coming years (Verkerk et al. 2011). Harkin and Rowe (1971) demonstrated that the average heating value of $10 \mathrm{~T}$ of totally dried bark is equal to the heating value of $7 \mathrm{~T}$ coal. The heating value of the bark per kilogram is similar to wood, at 16.20 to $16.23 \mathrm{MJ} / \mathrm{kg}$ (Corder 1976; Pecznik and Körmendi 2002; Dibdikova et al. 2014). Bark waste produced in large numbers usually has high moisture content, which significantly reduces the efficiency of energetic utilization, as most of the energy is needed to evaporate the moisture content. Bark with over $60 \%$ net moisture content cannot be burned effectively (Molnár 2004). When using bark as briquettes, it is usually mixed with straw and sawdust. Adding wax increases the solidity of biomass briquettes, but the additive can reduce the moisture content as well. Its most important characteristic is its high density and compactness (1.0 to $1.3 \mathrm{~g} / \mathrm{cm}^{3}$ ) (Baros 2003). In Norway, the bark of Scotch pine was examined as a potential raw material. The experiment was performed with 5, 10, 30, and 100\% bark content. Durability was similar in all classes. Its density was higher than pure wood pellets. More bark in the mixture resulted in a higher the ash content; the best quality class was the $10 \%$ mixture with $0.7 \%$ ash content (Filbakk et al. 2011).

Melin (2008) found that bark can be used to produce pellets, and, moreover, as it is cheaper than wood, it will probably become one of the main raw materials of processing pellets. Because of materials in bark that melt easily in high pressure, the bond among particles is strong; therefore, pellets made of bark have advantageous physical and mechanical qualities. As for disadvantages, the high ash content and the presence of materials (chlorides, sulphates) require special measures. Similar results were found by Lehtikangas (2001), who found that besides suitability, bark pellets have excellent durability and tolerate moisture well.

Melekhov et al. (2015) studied the energy potential of bark in a resource-saving program, suggesting the thermomodification of birch bark for changes in physical- 
mechanical properties, which greatly simplifies further technology to turn it into pelletized fuel.

Gil (1997) suggested using the waste and dust produced during cork processing to generate energy because it has high calorific value.

Obernberger and Thek (2004) examined the suitability of increased density biomass fuels according to standards and found that density, ash and water content, gross and net heating value, $\mathrm{C}, \mathrm{H}, \mathrm{N}, \mathrm{S}, \mathrm{Cl}, \mathrm{K}$, and attrition were influenced by the $\mathrm{Cd}, \mathrm{Pb}, \mathrm{Zn}, \mathrm{Cr}, \mathrm{Cu}$, $\mathrm{As}$, and $\mathrm{Hg}$ content. The examined pellets met the Austrian, German, Swiss, and Swedish standards.

Using a special measurement device, Kamikawa et al. (2009) found that although the total amount of heat energy extractable from bark does not differ from the extractable quantity from wood, there is difference; bark pellets dissipate less heat during burning and give off more sparks.

\section{AGRICULTURE}

The simplest agricultural utilization of bark is mulching. The advantages of mulching are that it reduces evaporation on the soil surface, helps the reproduction of microorganisms, and decays more slowly than wood. Because of its lower "nitrogenintake," less artificial fertilizer is needed when mulch is used. Bark mixed into heavy soil works to aerify it, prevent compaction, increase water absorption, and reduce erosion of the soil. However, not all types of bark are suitable for mulching because of their high chemical content (Young 1937; Nagy et al. 1998; Whiting et al. 2015), and, according to Harkin and Rowe (1971), their high costs of delivery. In seedling nurseries, 2 to $3 \mathrm{~cm}$ mulching of bark flour, made neutral with the addition of lime, created conditions comparable to forest conditions (Bittner and Schneider 1975). Chipped and classified spruce, Scotch pine, and oak bark provide plants with nutritives from their decay products, and they are successfully used when growing vegetables and strawberries (Blossfeld 1977).

Bark in natural circumstances decays slowly, mainly due to its low nitrogen content. Composting can speed up decay; four months outdoors are needed if the bark is chipped into smaller than $10 \mathrm{~mm}$ pieces (Bersenev 1975). Bark can be used as a growing medium after more years of ripening, and during this time, its humus state, adsorption, puffer capacity, and ability to moisten increases (Sári 2008). Composting is influenced by the different proportion of protective materials in the bark (e.g., resins, fats, tannins, and phenols) (Gerencsér 2010). Bark with proper preparation has the same value as peat (Asztalos and Szabó 1975). Mass production experiments were started in Poland in 1973, when 10,000 t bark were composted. In 1974, the experiment continued and 30,000 t of composted bark was produced. The main users of bark compost have been city park builders and the private sector (Asztalos 1977). An environmentally friendly plantconditioning product containing willow bark is being developed (Ábri et al. 2010).

Bark can be used as litter as well. Its advantageous characteristic is that it binds the ammonia content of air and moisture. Litter made of bark ground smaller than 4 to $5 \mathrm{~mm}$ had no harmful effect on the nutrition and weight gain of poultry stock when the bark of broad-leafed and coniferous species was used (Labosky et al. 1977).

Compared with wood, bark is less suitable for the direct feeding of animals. Feeding sheep with ensilaged, chipped common aspen bark did not have favorable results (Dudkin and Darman'jan 1978). 


\section{PRODUCTION OF BOARDS}

The production of bark-based particle boards and fiberboards has been investigated, but by contaminants on the bark (sand containing silicon-dioxide and soil) limit the production of particle boards (Deppe and Ernst 1977). Another difficulty was that the increased proportion of bark particles corresponded with a decline in solidity because the mechanical properties of the bark not as good as wood (Kelly 1977). Dost (1971) examined redwood three-layer particleboards that contained 0,10,20, and 30\% bark, using three different resin levels. Increased bark content at all resin levels resulted in the fall of the modulus of rupture (MOR), the modulus of elasticity (MOE), and the dimensional stability; however, the $24 \mathrm{~h}$ water intake decreased. Chen et al. (1972) made particle boards using whole Picea abies entities combined with chips of traditional debarked spruce. The particle boards made from the whole tree did not meet the standard bending strength requirements, but the 1:1 proportion mix with debarked spruce did.

Heebink (1974) used Pinus contorta harvesting losses; its average bark content was 7\%. Differently structured particle boards were produced from these materials without difficulty. Lehmann and Geimer (1974) produced particle boards with the help of different forest waste and harvesting losses, finding that strong and stable boards can be produced if the bark content remains under 12\%. Muszynski and McNatt (1984) examined Picea abies and Pinus sylvestris bark in particle boards with the bark content varied between 0 and $100 \%$ in $10 \%$ steps. The physical and mechanical examination showed that even the $30 \%$ bark content boards were suitable for producing furniture. Chow et al. (2008) examined the wood and bark of Parthenium argentatum and found that it can be used for direct substitution of wood based fiber. This tree was suitable for producing hypoallergenic latex as well. Gertjejansen and Haygreen (1973) examined the physical properties of particle boards made of common aspen. The whole trunk could be used to produce particle boards if the bark of the lower trunk was not used, as it drastically reduced linear stability. Stayton et al. (1971) used aspen and paper birch flakes pure, and mixed to make one-layer particleboard. They tested the strength, stiffness, dimensional stability, and appearance and all boards had commercially acceptable moduli of rupture and elasticity, internal bond, and linear and thickness as well.

Anderson et al. (1974a, 1974b, 1974c) studied particle boards glued with bark extractive and bark core particle boards. The boards made from only bark were not suitable because of low MOR values and large linear shrinkage values, but the bark core boards had satisfying qualities. Starecki (1979) produced one- and three-layer boards using waste bark material from the cellulose and paper industry. The bark amount was varied between 0 and $100 \%$. The bending strength decreased due to the bark ratio. Experimental products where the middle part contained $65 \%$ bark met the standards of that time. Compared with pure bark boards, the boards made from bark and chip combinations showed three times greater bending strength.

The bark of black spruce and spruce has been used to produce particle boards. Under certain conditions, it was technologically possible for particle boards to contain bark. The best mechanical properties were reached with 50\% wood and $14 \%$ resin content (Blanchet et al. 2000). Different opinions arose concerning the approximate recommended amount of bark in the middle of a particle board. Kehr (1979) adopted the point of view that wood material with over $10 \%$ bark ratio in its middle part can only be used with density increase, which meant surplus expenditure. A study in white birch showed that the production of particle boards could be $70 \%$ cheaper by adding bark, and in such way that 
the mechanical properties do not weaken (Pedieu et al. 2009). Nemli and Çolakoğlu (2005) determined some mechanical characteristics of locust and mimosa bark particle boards; the formaldehyde emission, tensile strength, MOE, inner bond strength, and the thickness of boards were examined. By using bark, the formaldehyde emission significantly decreased, and the inner bond strength increased.

In another study, the bond strength of PF-A and PF-B resins was examined (veneer board glue) where acacia bark dust was used in different concentrations. The bond strength of PF-A increased, while the solidity of PF-B resin did not change (Miyazaki et al. 2011) The Acacia mangium is a fast growing species that is planted in many countries. The tree has about $10 \%$ bark content, $20 \%$ of which is extract material (tannins) (Hoong et al. 2009). The wood is mainly the raw material of veneer and paper production. The extract of the bark is rich in phenol compounds and can potentially replace phenol-formaldehyde (PF) glues in the plywood processing industry. However, to have a suitable effect, resin must be mixed with the extracts (Hoong et al. 2011). Gupta (2009) produced boards from Pinus contorta bark without adding resin, although their physical-mechanical properties did not reach the minimal values given in standards.

The studies of Pedieu et al. (2008a, 2008b) examined the hydrophobic properties of the outer bark of Betula papyrifera, hypothesizing that the particles of the Betula papyrifera outer bark would improve the size stability of the produced mixed particle board. The results of the study unambiguously established that boards could be produced using not more than $45 \%$ bark to meet the desired mechanical and physical requirements.

MDF boards were produced using the bark of four tree species (hybrid poplar, jack pine, larch, and spruce). The refined bark fibers had bigger volume density than that of the control wood (Cheng et al. 2006).

The use of bark as thermal insulation board is still in its infancy. It is unclear how the lumbering difficulties, quality differences, and difficult handling could be tolerated. Because bark usually has a lower fiber content than wood, its solidity is lower as well, but in Scandinavia, it still meets standards. Some trees have a relatively high resin and wax content that is advantageous because no glue is necessary when clamping boards together; it is enough to press at high temperatures. These boards are made mixed with wood chips where the bark content is usually 25\% (Harkin and Rowe 1971). Kain et al. (2012) made insulation boards out of Pinus sylvestris bark, producing comparatively light bark boards for thermal insulation. The heat storage capacity was superior to commonly known insulation materials. Kain et al. (2013a) used spruce bark pieces as blow thermal insulation while making insulation for a log wall on which winter temperature was simulated. The temperature profile was modelled. Bark conducted heat more slowly than other materials used for blowing, so it can be used as insulation material. Kain et al. (2013b) made insulating boards using bark from Pinus sylvestris, Picea abies, and Abies alba. They found that the heat and sound insulating properties were very good, and its mechanical properties met requirements. Moreover, its formaldehyde emission was low. The bark of Larix decidua is suitable for thermal insulation boards, which have relatively low coefficients of thermal conductivity (0.065-0.09 W/mK) (Kain et al. 2014). Moreover, the boards could be glued with tannin resin, free from formaldehydes and artificial resins, so it was more environmentally friendly.

Cryptomeria japonica is widely used in the construction industry in Japan, but its bark (which is rich in fiber and long lasting) is removed. Experiments were made on its thermal insulation properties in which it was coarsely and finely chopped, and boards were made with expanded polystyrene foam. The coarse and fine chopping did not make a 
difference, as the coefficients of thermal conductivity were 0.073 and $0.076 \mathrm{~W} / \mathrm{mK}$ in contrast with the $0.045 \mathrm{~W} / \mathrm{mK}$ of Styrofoam board (Sato et al. 2004).

Winkler (1978) made 4 to $5 \mathrm{~mm}$ thick boards from spruce bark. Their density was $900 \mathrm{~kg} / \mathrm{m}^{3}$, and the bending strength was over $2000 \mathrm{~N} / \mathrm{cm}^{2}$.

The subject of another study was the interaction of thermoplastic plastics with bark fibers by comparing bending strength and tensile strength. Black pine and common aspen bark fibers were used to produce composites. Stronger material was made from black pine composites, but its behavior was much more brittle than aspen composites. Most of their mechanical properties were lower than the control wood and plastic composites; the tensile strength and extension results were better than of the control material (Yemele et al. 2010). Attempts were made to produce injection-molded products with Douglas fir bark (Harkin and Rowe 1971).

Castro et al. (2010) examined cork-based sandwich-structured agglomerates, which were desired for use in airplanes. The performance of the sandwich structure was influenced by the size and density of cork granules and the method of sticking, and these parameters could be customized for final use. Hernández-Olivares et al. (1999) developed a new composite made of cork and gypsum, which were mutually compatible; composites were made with different density and functions with different mixing ratios, offering suitable thermal insulation and acoustic absorber properties.

Rudenko (2010) studied the influence of structure on the formation of plates from pine and larch bark and secondary polyethylene (PE). The best properties were observed for boards with $80 \% \mathrm{PE}$ and $20 \%$ bark. The MOR was $41 \mathrm{MPa}$, the density was $960 \mathrm{~kg} / \mathrm{m}^{3}$, the swelling on a thickness was $2 \%$, and the water absorption was $0.1 \%$.

\section{CORK UTILIZATION}

A special method of bark utilization is cork production (e.g., corks, insulation panels, etc.), achieved from the bark of cork oak (Quercus suber). The density of cork is 110 to $250 \mathrm{~kg} / \mathrm{m}^{3}$, and it is flexible, impermeable to fluids, and resistant to fungi, insects, and chemicals (Vajda 2006). Cork cells are brick-shaped, form lines perpendicular to the surface, and are densely arranged. They are found in the walls where suberin is deposited, so they soon necrose, with nothing remaining in them but air and secretions (Raymund 1940). Their chemical compounds are 58\% suberin, $22 \%$ cellulose, $12 \%$ lignin, and $8 \%$ additive materials (tannic acid, ash components). The material naturally has excellent characteristics. It is vapor permeable, waterproof and hydrophobic, cold and pest resistant, hardly combustible, resilient to shrinkage, and antistatic, and it is an effective heat insulator (its coefficient of thermal conductivity is small at 0.037 to $0.040 \mathrm{~W} / \mathrm{mK}$ ) and acoustic absorber.

The excellent characteristics of cork demonstrate that suberificated bark can protect wood (Molnár 2004). Şen et al. (2010) examined the phellom of the thick-barked Quercus cerris, which is indigenous to Eastern Europe and Asia Minor. While it was appropriate for making corks/bungs, the precondition was to separate the outer bark from the phloem. They also found (Şen et al. 2011) that the cork of Q. cerris var. cerris revealed typical phellom characteristics, but the size of cells was smaller. The proportion of cell wall was higher, and it contained more inclusions than $Q$. suber. Thus, it was mainly appropriate to make granules and different agglomerates (e.g., insulation). 


\section{OTHER UTILIZATIONS}

The chemical exploration of bark and the production of different compounds from it is growing more prominent. From the bark of durian, Oramahi and Diba (2013) used pyrolysis to produce acetic acid, wood spirit (alcohol methylicus), 2-propanon, and phenol derivate. From the bark of Pinus brutia, Şensöz (2003) produced bio-oil with a heating value of $31.03 \mathrm{MJ} / \mathrm{kg}$. Dedrie et al. (2015) examined the polyphenol content of Quercus robur and $Q$. petraea, which varied according to the time of lumbering and storing. The extract of Acacia mearnsii bark is a good source of natural polymers, which can be used in tanning agents and adhesives (Venter et al. 2012). The timber industry may be able to adapt bark extract to produce adhesives. The hydroxyl groups of phenolic substances react with formaldehyde, and the obtained bonding material can be successfully used to produce waterproof chipboards and plywood (Anderson et al. 1974b; Anderson and Wong 1975; Saayman et al. 1976). Sudakova et al. (2005) developed boron-containing protective compositions on the basis of the suberin of birch bark and lignin for combined bio- and fire protection of wooden construction material.

When fine-grained bark is mixed to the basic material of brick, which is burn out during baking, the porosity as well as the thermal insulation capacity of the brick can be increased. At the same time, because of the amount of burned material, the density of the bricks decreases (Schweizer 1975; Liversidge and Murray 1977; Schweizer and Meigel 1977).

With a special treatment, wicker bark is converted to a fiber-like material that can be used to produce felt boards, carton boards, wrapping material, and, especially, thermal insulation materials.

In the earthworks of Norwegian railways, chipped spruce and European silver fir bark have been used under the load-bearing layers without compressing as protection from frost (Schneider and Baums 1970).

\section{WATER AND GAS CLEANING/CLARIFICATION}

Bark or its modified version can be used to clean water. The bark of spruce, Scotch pine, larch, alder, linden, and elm binds poisonous lead, cadmium, mercury, and zinc ions (Randall et al. 1976). With activation by phosphoric acid, activated carbon can be produced from eucalyptus bark (Patnukao and Pavasant 2008). Because of its excellent adsorptive properties, activated carbon can be used to clean drinking water, to dispose of sewage water, remove air contamination, reclaim dissolvent, and whiten sugar. Palma et al. (2003) used chemically modified Pinus radiata bark and tannins to remove metal ions from water solutions and from the acid waste water of copper mine. The $\mathrm{pH}$ strongly influenced the metal adsorption ability. Modified tannins bound less metallic ions than the modified bark.

Salem and Awwad (2014) examined the fractional bio-sorption processes of modified Eriobotrya japonica bark on the water solutions of nickel ions. The rate of binding was influenced by the $\mathrm{pH}$, nickel ion concentration, amount of bark, contact time, and temperature. Modified medlar bark was successfully used to remove nickel ions from industrial galvanizing sewage. Kafle et al. (2015) tested the effectiveness of bark-based bio-filters on decontaminating the sewage of swine units from smell, $\mathrm{NH}_{3}$, and $\mathrm{H}_{2} \mathrm{~S}$. They determined that these bio-filters can be effectively used on swine farms, and they determined those pressure and time parameters that were essential to design filters. 
Cutillas-Barreiro et al. (2014) demonstrated that Pinus pinaster bark binds significant amounts of $\mathrm{Pb}^{2+}, \mathrm{Cu}^{2+}, \mathrm{Cd}^{2+}, \mathrm{Zn}^{2+}$, and $\mathrm{Ni}^{2+}$ ions, and therefore can be efficiently used for decontaminating heavy metal ions in polluted water. In another study (Vajda 2002), oillike compounds were decontaminated from sewage via bark. Treating oil acid emulsions with bark efficiently removed the low (under $1.0 \mathrm{~g} / \mathrm{L}$ ) and high (above $2.0 \mathrm{~g} / \mathrm{L}$ ) concentrated lipids from sewage. Semenovich et al. (2008) and Semenovich and Loskutov (2015) modified coniferous bark to collect spilled oil from water surfaces. The sorption capacity of modified bark reached $21.30 \mathrm{mg} / \mathrm{g}$ for $\mathrm{Cu}^{2+}, \mathrm{Co}^{2+}, \mathrm{Ca}^{2+}$, and $\mathrm{Zn}^{2+}$ cations, 42.10 $\mathrm{mg} / \mathrm{g}$ for dye methylene blue, and $8.23 \mathrm{~g} / \mathrm{g}$ for petroleum products.

The cleaning of gases has also been examined. To treat flue gas, bio-filters made from the bark of Pinus sylvestris, and the effect on industrial temperature and pressure (Andres et al. 2006). Valentín et al. (2010) propagated fungi (Phanerochaete velutina és Stropharia rugosoannulata) on Pinus sylvestris bark to produce lignolitic enzymes and peroxidase to clean polluted environments. The Pinus sylvestris bark helped produce enzymes and provided nutrients for fungi, thus the pine bark was appropriate for bioremediation.

\section{PLASTIC AND AGGREGATE PRODUCTION}

Cordeiro et al. (1997) examined the process and characteristics of suberin-based polyurethane. García et al. (2015) processed polyphenol-based polyurethane (PU) foils using condensed tannins, di-isocyanates, and hydroxil-tannin derivatives from the bark of Pinus pinaster.

Muñoz et al. (2013) examined the bark fibers of Eucalyptus nitens and found that its characteristics allowed its use it as a strengthening material for thermoplastic plastic such as high density polyethylene (HDPE).

Makarychev (2015) showed that tree bark filler increased the thermal capacity and thermal conductivity of thermoplastics, while thermal diffusivity remained constant.

Heinämäki et al. (2015) proved that fatty acids from suberin subtracted from Betula spp. bark significantly increased the vapor barrier characteristic of hydroxiprophilmethocel films, even in a low concentration.

\section{UTILIZATION AS CLOTHES AND POTS}

Li et al. (2014) found the relics of 7,900 yr-old clothes made from wood in SouthChina, and clothes are still made from wood today. Robertson (2014) described the traditional making of clothes from the bark of Ficus natalensis, which is indigenous to Africa. Bark has been used as ligament or wrapper since ancient times (Östlund et al. 2009). Pots made of bark (phloem) are often made from birch bark, but linden, poplar, and elms are also appropriate. Baskets, bowls, and wares are spun or woven from spirally peeled, soaked bark. Light bark wares can be used for decades (e.g., picking mushrooms or fruit). Sandals are also made from birch bark (Szatyor 1986). 


\section{REFERENCES CITED}

Åberga, G., Abrahamsen, G., Steinnes, E., and Hjelmseth, H. (2004). "Utilization of bark pockets as time capsules of atmospheric lead pollution in Norway," Atmospheric Environment 38(36), 6231-6237. DOI: 10.1016/j.atmosenv.2004.06.041

Ábri, J., Gömöry, P., and Horváth, A. (2010). “Természetes eredetű növénykondicionáló készítmény és eljárás annak alkalmazására" ("Plant conditioning composition of natural origin and process for using it"), Patent number WO2010150034 A2, Budapest, Hungary.

Abyshev, A. Z., Agaev, É. M., and Guseinov, A. B. (2007). "Studies of the chemical composition of birch bark extracts (Cortex betula) from the Betulaceae family," Pharmaceutical Chemistry Journal 41(8), 419-423. DOI: 10.1007/s11094-007-00915

Anderson, A. B., Wong, A., and Wu, K. T. (1974a). "Utilization of white fir bark in particleboard," Forest Products Journal 24(1), 51-54.

Anderson, A. B., Wong, A., and Wu, K. T. (1974b). "Utilization of white fir bark and its extracts in particleboard," Forest Products Journal 24(7), 40-45.

Anderson, A. B., Wong, A., and Wu, K. T. (1974c). "Utilization of ponderosa pine bark and its extracts in particleboard," Forest Products Journal 24(8), 48-53.

Anderson, A. B., and Wong, A. (1975). "Douglas fir and western hemlock bark extracts as bonding agents for particleboard," Forest Products Journal 25(3), 45-48.

Andres, Y., Dumont, E., Le Cloirec, P., and Ramirez-Lopez, E. (2006). "Wood bark as packing material in a biofilter used for air treatment," Environmental Technology 27(12), 1297-1301. DOI: 10.1080/09593332708618747

Annegowda, H. V., Gooi, T. S., Awang, S. H. H., Alias, N. A., Mordi, M. N., Ramanathan, S., and Mansor, S. M. (2012). "Evaluation of analgesic and antioxidant potency of various extracts of Cinnamomum iners bark," International Journal of Pharmacology 8(3), 198-203. DOI: 10.3923/ijp.2012.198.203

Asztalos, J. (1977). "A fakéreghasznosítás irányzatai a szocialista országokban" ("Tree barks utilization directions in Communist countries"), Faipar 27(8), 239-244.

Asztalos, J., and Szabó, P. (1975). "A fakéreg hasznosítása Lengyelországban” ("Wood bark utilization in Poland"), Faipar 25(12), 363-366.

Barboutis, I., and Lykidis, C. (2014). "The effects of bark on fuel characteristics of some evergreen Mediterranean hardwood species," in: Proceedings of the 57th International Convention of Society of Wood Science and Technology, Zvolen, Slovakia, pp. 533-540.

Barnes, D., Hamadan, M. A., and Ottaway, J. M. (1976). "The lead, copper and zinc content of tree rings and bark: A measurement of local metallic pollution," Science of the Total Environment 5(1), 63-67. DOI: 10.1016/0048-9697(76)90024-3

Baroth, R. (2005). "Literature review of the latest development of wood debarking," Report A No. 27, University of Oulu Control Engineering Laboratory, Oulu, Finland.

Bauer, G., Speck, T., Blomer, J., Bertling, J., and Speck, O. (2010). "Insulation capability of the bark of trees with different fire adaptation," Journal of Materials Science 45(21), 5950-5959. DOI: 10.1007/s10853-010-4680-4

Beisson, F., Li-Beisson, Y., and Pollard M. (2012). "Solving the puzzles of cutin and suberin polymer biosynthesis," Current Opinion in Plant Biology 15, 329-337. DOI 10.1016/j.pbi.2012.03.003 
Bellis, D. J., McLeod, C. W., and Satake, K. (2002a). " $\mathrm{Pb}$ and ${ }^{206} \mathrm{~Pb} /{ }^{207} \mathrm{~Pb}$ isotopic analysis of a tree bark pocket near Sheffield, UK recording historical change in airborne pollution during the $20^{\text {th }}$ Century," Science of the Total Environment 289(13), 169-176. DOI: 10.1016/S0048-9697(01)01037-3

Bellis, D. J., Satake, K., Noda, M., Nishimura, N., and McLeod, C. W. (2002b). "Evaluation of the historical records of lead pollution in the annual growth rings and bark pockets of a 250-year-old Quercus crispula in Nikko, Japan," Science of the Total Environment 295(1-3), 91-100. DOI: 10.1016/S0048-9697(02)00054-2

Berahou, A., Auhmani, A., Fdil, N., Benharref, A., Jana, M., and Gadhi, C. A. (2007). "Antibacterial activity of Quercus ilex bark's extracts," Journal of Ethnopharmacology 112(3), 426-429. DOI: 10.1016/j.jep.2007.03.032

Bersenev, R. S. (1975). "Использование коры на удобрения" ("The use of bark for fertilizer”), Derevoobrabatyvajushhaja Promyshlennost 12(27).

Berlizov, A. N., Blum, O. B., Filby, R. H., Malyuk, I. A., and Tryshyn, V. V. (2007). "Testing applicability of black poplar (Populus nigra L.) bark to heavy metal air pollution monitoring in urban and industrial regions," Science of the Total Environment 372(2-3), 693-706. DOI: 10.1016/j.scitotenv.2006.10.029

Bittner, A., and Schneider, A. (1975). "Wertvoller Humus aus Rinde" ("Valuable humus made of bark"), Holz-Zentralblatt 73-74, 956.

Blanchet, P., Cloutier, A., and Riedl, B. (2000). "Particleboard made from hammer milled black spruce bark residues," Wood Science and Technology 34(1), 11-19. DOI: $10.1007 / \mathrm{s} 002260050003$

Blossfeld, O. (1977). "Einsatzmöglichkeiten für Rinden sind geklärt," Informationen für den Industriezweig Schnittholz und Holzwaren 4, 319.

Boakye, P. A., Brierley, S. M., Pasilis, S. P., and Balemba, O. B. (2012). "Garcinia buchananii bark extract is an effective anti-diarrheal remedy for lactose-induced diarrhea," Journal of Ethnopharmacology 142(2), 539-547. DOI: 10.1016/j.jep.2012.05.034

Böhm, P., Wolterbeek, H., Verburg, T., and Musílek, L. (1998). "The use of tree bark for environmental pollution monitoring in the Czech Republic," Environmental Pollution 102(2-3), 243-250. DOI: 10.1016/S0269-7491(98)00082-7

Butterfield, B., Meylan, B., and Peszlen, I. (1997). A Fatest Háromdimenziós Szerkezete (Three dimensional structure of wood), Faipari Tudományos Alapítvány, Budapest, Hungary.

Castola, V., Bighelli, A., Rezzi, S., Melloni, G., Gladiali, S., Desjobert, J. M., and Casanova, J. (2002). "Composition and chemical variability of the triterpene fraction of dichloromethane extracts of cork (Quercus suber L.)," Industrial Crops and Products 15(1), 15-22. DOI: 10.1016/S0926-6690(01)00091-7

Castro, O., Silva, J. M., Devezas, T., Silva, A., and Gil, L. (2010). “Cork agglomerates as an ideal core material in lightweight structures," Materials and Design 31(1), 425432. DOI: 10.1016/j.matdes.2009.05.039

Catry, F. X., Rego, F., Moreira, F., Fernandes, P. M., and Pausas, J. G. (2010). "Post-fire tree mortality in mixed forests of central Portugal," Forest Ecology and Management 260(7), 1184-1192. DOI: 10.1016/j.foreco.2010.07.010

Chang, Y. P., and Mitchell, R. L. (1955). "Chemical composition of common North American pulpwood barks," Tappi 38(5), 315-320. 
Chen, T. Y., Paulitsch, M., and Soto, G. (1972). "On the suitability of the biological surface mass from spruce thinnings as raw material for particleboard," Holz als Rohund Werkstoff 30(1), 15-18. DOI: 10.1007/BF02615026

Cheng, X., Deng, J., Zhang, S. Y., Riedl, B., and Cloutier, A. (2006). "Impact of bark content on the properties of medium density fiberboard (MDF) in four species grown in eastern Canada," Forest Products Journal 56(3), 64-69.

Chow, P., Nakayama, F. S., Blahnik, B., Youngquist, J. A., and Coffelt, T. A. (2008). "Chemical constituents and physical properties of guayule wood and bark," Industrial Crops and Products 28(3), 303-308. DOI: 10.1016/j.indcrop.2008.03.006

Chow, S., and Obermajer, A. (2004). "Wood-to-bark adhesion of subalpine fir (Abies lasiocarpa) in extreme temperatures," Wood Science and Technology 38(6), 391-403. DOI: $10.1007 / \mathrm{s} 00226-004-0247-3$

Clark, III., A., Phillips, D. R., and Frederick, D. J. (1985). Weight, Volume, and Physical Properties of Major Hardwood Species in the Gulf and Atlantic Coastal Plains (Research Paper SE-250), U. S. Department of Agriculture, Southeastern Forest Experiment Station, Asheville, NC, USA.

Comandini, P., Lerma-García, M. J., Simó-Alfonso, E. F., and Toschi, T. G. (2014). "Tannin analysis of chestnut bark samples (Castanea sativa Mill.) by HPLC-DADMS," Food Chemistry 157, 290-295. DOI: 10.1016/j.foodchem.2014.02.003

Conkova, M., and Kubiznakova, J. (2008). "Lead isotope ratios in tree bark pockets: An indicator of past air pollution in the Czech Republic," Science of the Total Environment 404(2-3), 440-445. DOI: 10.1016/j.scitotenv.2008.04.025

Coquet, C., Ferré, E., Peyronel, D., Farra, C. D., and Farnet, A. M. (2008). "Identification of new molecules extracted from Quercus suber L. cork," Comptes Rendus Biologies 331(11), 853-858. DOI: 10.1016/j.crvi.2008.08.011

Cordeiro, N., Belgacem, M. N., Gandini, A., and Neto, C. P. (1997). "Urethanes and polyurethanes from suberin: 1. Kinetic study," Industrial Crops and Products 6(2), 163-167. DOI: 10.1016/S0926-6690(96)00212-9

Cordeiro, N., Belgacem, M. N., Silvestre, A. J. D., Neto, C. P., and Gandini, A. (1998). "Cork suberin as a new source of chemicals: 1 . Isolation and chemical characterization of its composition," International Journal of Biological Macromolecules 22(2), 71-80. DOI: 10.1016/S0141-8130(97)00090-1

Corder, S. E. (1976). Properties and Uses of Bark as an Energy Source (Research Paper 31), Oregon State University Forest Research Laboratory, Corvallis, OR, USA.

Cutillas-Barreiro, L., Ansias-Manso, L., Fernández-Calviño, D., Arias-Estévez, M., Nóvoa-Muñoz, J. C., Fernández-Sanjurjo, M. J., Álvarez-Rodríguez, E., and NúñezDelgado, A. (2014). "Pine bark as bio-adsorbent for $\mathrm{Cd}, \mathrm{Cu}, \mathrm{Ni}, \mathrm{Pb}$ and $\mathrm{Zn}$ : Batchtype and stirred flow chamber experiments," Journal of Environmental Management 144, 258-264. DOI: 10.1016/j.jenvman.2014.06.008

Dedrie, M., Jacquet, N., Bombeck, P. L., Hébert, J., and Richel, A. (2015). 'Oak barks as raw materials for the extraction of polyphenols for the chemical and pharmaceutical sectors: A regional case study," Industrial Crops and Products 70, 316-321. DOI: 10.1016/j.indcrop.2015.03.071

Deineko, I. P., Faustova, N. M. (2015). "Element and group chemical composition of aspen bark and wood," Chemistry of Plant Raw Material 1, 51-62. DOI: 10.14258/jcprm.201501461

Deppe, H. J., and Ernst, K. (1977). Taschenbuch der Spanplattentechnik, DRW-Verlag, Stuttgart, Germany. 
Dibdiakova, J., Gjølsjø, S., and Wang, L. (2014). Solid Biofuels from Forest - Fuel Specification and Quality Assurance. Inherent Properties of Norway Spruce Biomass in Some Geographical Locations in South Norway, Norwegian Forest and Landscape Institute, Ås, Norway.

Dickinson, M. B. (2002). "Heat transfer and vascular cambium necrosis in the boles of trees during surface fires," in: Forest Fire Research \& Wildland Fire Safety: Proceedings of IV International Conference on Forest Fire Research, D. X. Viegas (ed.), Coimbra, Portugal.

Dickinson, M. B., and Johnson, E. A. (2001). "Fire effects on trees," in: Forest Fires: Behavior and Ecological Effects, E. A. Johnson and K. Miyanishi (eds.), Academic Press, New York, NY, USA. DOI: 10.1016/b978-012386660-8/50016-7

Diouf, P. N., Stevanovic, T., and Cloutier, A. (2009). "Study on chemical composition, antioxidant and anti-inflammatory activities of hot water extract from Picea mariana bark and its proanthocyanidin-rich fractions," Food Chemistry 113(4), 897-902. DOI: 10.1016/j.foodchem.2008.08.016

Do Vale, A. T., and Elias, P. S. (2014). "Bark thermal protection level of four tree species and the relationship between bark architecture and heat transfer," Ciência Florestal, Santa Maria 24(4), 979-987. DOI: 10.5902/1980509816611

Dost, W. A. (1971). "Redwood bark fiber in particleboard," Forest Products Journal 21(10), 38-43.

Dudkin, M. S., and Darman'jan, P. M. (1978). “Древесина и отходы ее переработки как кормовые продукты” (“Wood and its processing wastes as feed products”), Himija Drevesiny 1, 3-17.

Einspahr, D. W., Van Eperen, R. H., and Fiscus, M. L. (1984). "Morphological and bark strength characteristics important to wood/bark adhesion in hardwoods," Wood and Fiber Science 16(3), 339-348.

El-Hasan, T., Al-Omari, H., Jiries, A., and Al-Nasir, F. (2002). "Cypress tree (Cupressus semervirens L.) bark as an indicator for heavy metal pollution in the atmosphere of Amman City, Jordan," Environment International 28(6), 513-519. DOI: 10.1016/S0160-4120(02)00079-X

FAO (2015). FAO Forestry Series No. 48 FAO Statistics Series No. 204, Forest Products 2009-2013. Rome, Italy. http://www.fao.org/3/a-i4746m.pdf

Fatoki, O. S., and Ayodele, E. T. (1991). "Zinc and copper levels in tree barks as indicators of environmental pollution," Environment International 17(5), 455-460. DOI: 10.1016/0160-4120(91)90279-Y

Fekete, Z. (1951). Erdőbecsléstan ("Estimation of forest stocks"), Akadémiai Kiadó, Budapest, Hungary.

Feng, S., Cheng, S., Yuan, Z., Leitch, M., and Xu, C. (2013). "Valorization of bark for chemicals and materials: A review," Renewable and Sustainable Energy Reviews 26, 560-578. DOI: 10.1016/j.rser.2013.06.024

Fernandes, A., Sousa, A., Mateus, N., Cabral, M., and de Freitas, V. (2011). "Analysis of phenolic compounds in cork from Quercus suber L. by HPLC-DAD/ESI-MS," Food Chemistry 125(4), 1398-1405. DOI: 10.1016/j.foodchem.2010.10.016

Filbakk, T., Jirjis, R., Nurmi, J., and Høibø, O. (2011). "The effect of bark content on quality parameters of Scots pine (Pinus sylvestris L.) pellets," Biomass and Bioenergy 35(8), 3342-3349. DOI: 10.1016/j.biombioe.2010.09.011

Fodor, F. (2004). "Fásult személyi- Az árulkodó fakéreg" ("Woody ID; informing bark"), Természetbúvár 59(3), 2-5. 
Fradinho, D. M., Neto, C. P., Evtuguin, D., Jorge, F. C., Irle, M. A., Gil, M. H., and Pedrosa de Jesus, J. (2002). "Chemical characterisation of bark and of alkaline bark extracts from maritime pine grown in Portugal," Industrial Crops and Products 16(1), 23-32. DOI: 10.1016/S0926-6690(02)00004-3

Gandini, A., Neto, C. P., and Silvestre, A. J. D. (2006). "Suberin: A promising renewable resource for novel macromolecular materials," Progress in Polymer Sciences 31(10), 878-892. DOI: 10.1016/j.progpolymsci.2006.07.004

García, D. E., Glasser, W. G., Pizzi, A., Paczkowski, S., and Laborie, M. P. (2015). "Hydroxypropyl tannin from Pinus pinaster bark as polyol source in urethane chemistry," European Polymer Journal 67, 152-165. DOI: 10.1016/j.eurpolymj.2015.03.039

Gemici, M., Gemici, Y., and Tan, K. (2006). "Sulphur content of red pine (Pinus brutia) needles and bark as indicator of atmospheric pollution in southwest Turkey," Phytologia Balcanica 12(2), 267-272.

Gerencsér, K. (2010). "Fürészipari technológia" ("Wood sawing technology”), lectures, University of West Hungary, Hungary.

Gertjejansen, R., and Haygreen, J. G. (1973). "Effect of aspen bark from butt and upper logs on the physical properties of wafer-type and flake-type particleboards," Forest Products Journal 23(9), 66-71.

Ghosh, D. (2006). "Bark is the hallmark," Resonance 11(3), 41-50. DOI: $10.1007 / \mathrm{bf02835967}$

Gil, L. (1997). "Cork powder waste: An overview," Biomass and Bioenergy 13(1-2), 5961. DOI: 10.1016/S0961-9534(97)00033-0

Graça, J. (2015). "Suberin: The biopolyester at the frontier of plants," Frontiers in Chemistry 3, 62. DOI: 10.3389/fchem.2015.00062

Graça, J., and Santos, S. (2006a). "Glycerol-derived ester oligomers from cork suberin," Chemistry and Physics of Lipids 144(1), 96-107. DOI:

10.1016/j.chemphyslip.2006.08.001

Graça, J., and Santos, S. (2006b). "Linear aliphatic dimeric esters from cork suberin," Biomacromolecules 7, 2003-2010. DOI: 10.1021/bm060174u

Grace, O. M., Prendergast, H. D. V., Jager, A. K., and van Staden, J. (2003). “Bark medicines used in traditional healthcare in KwaZulu-Natal, South Africa: An inventory," South African Journal of Botany 69(3), 301-363. DOI: 10.1016/S02546299(15)30318-5

Grigorjuk, G. P., Slastnikov, I. I., Starostina, E. B., Prodaevich, V. G., Levin, D. V. (2010). "Method for processing of conifer bark," Russia Patent number 2,400,357.

Grodzinska, K. (1971). "Acidification of tree bark as a measure of air pollution in southern Poland," Bulletin of the Polish Academy of Sciences, Cl. 2, Sér. Sci. Biol., 19(3), 189-195.

Grodzinska, K. (1978). "Acidity of tree bark as a bioindicator of forest pollution in southern Poland," Water, Air, and Soil Pollution 8, 3-7.

Grodzinska, K. (1979). "Tree-bark - sensitive biotest for environment acidification," Environment International 2(3), 173-176. DOI: 10.1016/0160-4120(79)90075-8

Grodzinska, K. (1982). "Monitoring of air pollutants by mosses and tree bark," in: Monitoring of Air Pollutants by Plants - Methods and Problems, L. Steubing, and H.J. Jäger (eds.), W. Junk Publishers, The Hague, Netherlands, pp. 33-42. 
Guidi, W., Piccioni, E., Ginanni, M., and Bonari, E. (2008). "Bark content estimation in poplar (Populus deltoides L.) short-rotation coppice in central Italy," Biomass and Bioenergy 32(6), 518-524. DOI: 10.1016/j.biombioe.2007.11.012

Gupta, G. K. (2009). Development of Bark-based Environmental-friendly Composite Panels, Master's thesis, University of Toronto, Toronto, Canada.

Li, H. E., Li, B. T., and Lan, S. F. (2008). "Responses of the urban roadside trees to traffic environment," in: Proceedings from the Fourth International Conference on Environmental Science and Technology, Houston, Texas, USA, pp. 63-70.

Hargitai, L. (2003). Fürészáru (Timber products), Szaktudás Kiadó Ház Rt., Budapest Hungary.

Harkin, J. M., and Rowe, J. W. (1971). Bark and its Possible Uses (Research Note FPL091), U.S. Department of Agriculture, Forest Products Laboratory, Madison, WI, USA.

Härtel, O. (1982). "Pollutants accumulation by bark," in: Monitoring of Air Pollutants by Plants - Methods and Problems, L. Steubing, and H.-J. Jäger (eds.), W. Junk Publishers, The Hague, Netherlands, pp. 137-147.

Kuik, P., and Wolterbeek, H. T. (1994). "Factor analysis of trace-element data from treebark samples in the Netherlands," Environmental Monitoring and Assessment 32(3), 207-226. DOI: 10.1007/BF00546277

Hakkila, P. (1989). Utilization of Residual Forest Biomass, Springer-Verlag, Berlin, Germany.

Heebink, B. G. (1974). Particleboards from Lodgepole Pine Forest Residue (Research Paper FPL 221), U.S. Department of Agriculture, Forest Products Laboratory, Madison, WI, USA.

Heinämäki, J., Halenius, A., Paavo, M., Alakurtti, S., Pitkänen, P., Pirttimaa, M., Paaver, U., Kirsimäe, K., Kogermann, K., and Yliruusi, J. (2015). "Suberin fatty acids isolated from outer birch bark improve moisture barrier properties of cellulose ether films intended for tablet coatings," International Journal of Pharmaceutics 489(1-2), 91-99. DOI: 10.1016/j.ijpharm.2015.04.066

Hengst, G. E., and Dawson, J. O. (1993). "Bark thermal properties of selected central hardwood species," in: Proceedings, $9^{\text {th }}$ Central Hardwood Forest Conference, A. R. Gillespie, G. R. Parker, P. E. Pope, and G. Rink (eds.), West Lafayette, IN, USA, pp. 55-75.

Hernández-Olivares, F., Bollati, M. R., del Rio, M., and Parga-Landa, B. (1999). "Development of cork-gypsum composites for building applications," Construction and Building Materials 13(4), 179-186. DOI: 10.1016/S0950-0618(99)00021-5

Hoong, Y. B., Paridah, M. T., Loh, Y. F., Jalaluddin, H., and Chuah, L. A. (2011). “A new source of natural adhesive: Acacia mangium bark extracts co-polymerized with phenol-formaldehyde (PF) for bonding Mempisang (Annonaceae spp.) veneers," International Journal of Adhesion and Adhesives 31(3), 164-167. DOI: 10.1016/j.ijadhadh.2010.12.002

Hoong, Y. B., Paridah, M. T., Luqman, C. A., Koh, M. P., and Loh, Y. F. (2009). "Fortification of sulfited tannin from the bark of Acacia mangium with phenolformaldehyde for use as plywood adhesive," Industrial Crops and Products 30(3), 416-421. DOI: 10.1016/j.indcrop.2009.07.012

Jové, P., Olivella, M. À., and Cano, L. (2011). "Study of the variability in chemical composition of bark layers of Quercus suber L. from different production areas," BioResources 6(2), 1806-1815. DOI: 10.15376/biores.6.2.1806-1815 
Jyske, T., Laakso, T., Latva-Mäenpää, H., Tapanila, T., and Saranpää, P. (2014). "Yield of stilbene glucosides from the bark of young and old Norway spruce stems," Biomass and Bioenergy 71, 216-227. DOI: 10.1016/j.biombioe.2014.10.005

Kafle, G. K., Chen, L., Neibling, H., and He, B. B. (2015). "Field evaluation of wood bark-based down-flow biofilters for mitigation of odor, ammonia, and hydrogen sulfide emissions from confined swine nursery barns," Journal of Environmental Management 147, 164-174. DOI: 10.1016/j.jenvman.2014.09.004

Kain, G., Barbu, M. C., Hinterreiter, S., Richter, K., and Petuschnigg, A. (2013a). "Using bark as a heat insulation material," BioResources 8(3), 3718-3731. DOI: 10.15376/biores.8.3.3718-3731

Kain, G., Güttler, V., Barbu, M. C., Petutschnigg, A., Richter, K., and Tondi, G. (2014). "Density related properties of bark insulation boards bonded with tannin hexamine resin," European Journal of Wood and Wood Products 72(4), 417-424. DOI: 10.1007/s00107-014-0798-4

Kain, G., Heinzmann, B., Barbu, M. C., and Petutschnigg, A. (2013b). "Softwood bark for modern composites," Pro Ligno 9(4), 460-468.

Kamikawa, D., Kuroda, K., Inoue, M., Kubo, S., and Yoshida, T. (2009). "Evaluation of combustion properties of wood pellets using a cone calorimeter," Journal of Wood Sciences 55, 453-457. DOI: 10.1007/s10086-009-1061-1

Kehr, E. (1979). "Untersuchungen zum Einfluss der Rinde bei der Verarbeitung unentrindeten Holzes in der Deckschicht von Spanplatten," Holztechnologie 20, 3239.

Kelly, M. W. (1977). Critical Literature Review of Relationships Between Processing Parameters and Physical Properties of Particleboard (General Technical Report, Forest Products Laboratory 10), U.S. Department of Agriculture Forest Products Laboratory, Madison, WI, USA.

Kemppainen, K., Siika-aho, M., Pattathil, S., Giovando, S., and Kruus, K. (2014). "Spruce bark as an industrial source of condensed tannins and non-cellulosic sugars," Industrial Crops and Products 52, 158-168. DOI: 10.1016/j.indcrop.2013.10.009

Kim, Y. G., Lee, J. H., Kim, S. I., Baek, K. H., and Lee, J. (2015). "Cinnamon bark oil and its components inhibit biofilm formation and toxin production," International Journal of Food Microbiology 195, 30-39. DOI: 10.1016/j.ijfoodmicro.2014.11.028

Kiran, A. W., and Chandrakant, S. M. (2009). "Pharmacognostic profiles of bark of Careya arborea Roxb," Journal of Pharmacognosy and Phytotherapy 1(5), 64-66.

Kotina, E. L., Van Wyk, B. E., and Tilney, P. M. (2014). "Anatomy of the leaf and bark of Warburgia salutaris (Canellaceae), an important medicinal plant from South Africa," South African Journal of Botany 94, 177-181. DOI: 10.1016/j.sajb.2014.06.008

Kuang, Y. W., Zhou, G. Y., Wen, D. Z., and Liu, S. Z. (2006). "Acidity and conductivity of Pinus massoniana bark as indicators to atmospheric acid deposition in Guangdong, China," Journal of Environmental Sciences 18(5), 916-920. DOI: 10.1016/S10010742(06)60014-4

Kuznetsov, B. N., Levdansky, V. A., Kuznetsova, S. A. (2015). Химические продукты из древесной коры" (Chemical products made of bark), Moscow, Russia.

Labosky, Jr., P., Holleman, K. A., Dick, J. W., and So, D. T. (1977). "Utilization of bark residues as poultry litter," Forest Products Journal 1, 28-32. 
Lambert, M. J. (1981). "Inorganic constituents in wood and bark of New South Wales forest tree species," Forestry Commission of New South Wales, Research Note No. 45. Sydney, Australia.

Lawes, M. J., Richards, A., Dathe, J., and Midgley, J. J. (2011). "Bark thickness determines fire resistance of selected tree species from fire-prone tropical savanna in north Australia," Plant Ecology 212(12), 2057-2069. DOI: 10.1007/s11258-0119954-7

Le Normand, M., Mélida, H., Holmbom, B., Michaelsen, T. E., Inngjerdingen, M., Bulone, V., Paulsen, B. S., and Ek, M. (2014). "Hot-water extracts from the inner bark of Norway spruce with immunomodulating activities," Carbohydrate Polymers 101, 699-704. DOI: 10.1016/j.carbpol.2013.09.067

Lehmann, W. F., and Geimer, R. L. (1974). "Properties of structural particleboards from Douglas fir forest residues," Forest Products Journal 24(10), 17-25.

Lehtikangas, P. (2001). "Quality properties of pelletised sawdust, logging residues and bark," Biomass and Bioenergy 20, 351-360. DOI: 10.1016/S0961-9534(00)00092-1

Li, D., Wang, W., Tian, F., Liao, W., and Bae, C. J. (2014). "The oldest bark cloth beater in southern China (Dingmo, Bubing basin, Guangxi)," Quaternary International 354, 184-189. DOI: 10.1016/j.quaint.2014.06.062

Lin, H., Zhang, Y. W., Bao, Y. L., Wu, Y., Sun, L. G., Yu, C. L., Huang, Y. X., Wang, E. B., and Li, Y. X. (2013). "Secondary metabolites from the stem bark of Juglans mandshurica," Biochemical Systematics and Ecology 51, 184-188. DOI: 10.1016/j.bse.2013.08.010

Lippo, H., Poikolainen, J., and Kubin, E. (1995). "The use of moss, lichen and pine bark in the nationwide monitoring of atmospheric heavy metal deposition in Finland," Water, Air, and Soil Pollution 85, 2241-2246. DOI: 10.1007/BF01186167

Liu, Z., Zhang, X., Cui, W., Zhang, X., Li, N., Chen, J., Wong, A. W., and Roberts, A. (2007). "Evaluation of short-term and subchronic toxicity of magnolia bark extract in rats," Regulatory Toxicology and Pharmacology 49(3), 160-171. DOI: 10.1016/j.yrtph.2007.06.006

Liversidge, R. M., and Murray, M. H. (1977). "Possible use of sawdust in clay building bricks should help many sawmillers," Australian Forest Industries 43(2), 48-49.

Lötschert, W. (1983). "Immissions analysen im Raum Frankfurt unter Verwendung pflan-zlicher Biodinidkatoren," Verhandlungen der Gesellschaft für Ökologie 11, 277-290.

Makarychev, S. V. (2015). "Thermophysical properties of thermoplastics made on the basis of wood wastes," Altai State Agricultural University Bulletin 6(128), 139-142.

Mandiwana, K. L., Resane, T., Panichev, N., and Ngobeni, P. (2006). "The application of tree bark as bio-indicator for the assessment of $\mathrm{Cr}(\mathrm{VI})$ in air pollution," Journal of Hazardous Materials 137(2), 1241-1245. DOI: 10.1016/j.jhazmat.2006.04.015

Marmor, L., and Randlane, T. (2007). "Effects of road traffic on bark pH and epiphytic lichens in Tallinn," Folia Cryptogamica Estonica, Fasc. 43, 23-37.

Martin, R. E., and Crist, J. B. (1970). "Elements of bark structure and terminology," Wood and Fiber Science 2(3), 269-279.

Melekhov, V. I., Tyurikova, T. V., Ponomareva, N. G. (2015). "Energy potential of bark in resource saving program," Current Research Areas of the XXI Century: Theory and Practice, 9-3(20-3), 106-110. DOI: 10.12737/16877

Melin, S. (2008). "Bark as feedstock for production of wood pellets," Wood Pellet Association of Canada, (http://www.pellet.org/images/2008-12- 
11_Bark_as_feedstock_for_Production_of_Wood_Pellets_Report_December_2008.p df).

Miles, P. D., and Smith, W. B. (2009). Specific Gravity and Other Properties of Wood and Bark for 156 Tree Species Found in North America, U.S (Research Note Northern Research Station 38), , U.S. Department of Agriculture, U.S. Forest Service, Newtown Square, PA, USA.

Millkin, D. E. (1955). "Determination of bark volumes and fuel properties," Pulp and Paper Magazine of Canada 56(13), 106-108.

Miranda, I., Gominho, J., Mirra, I., and Pereira, H. (2012). "Chemical characterization of barks from Picea abies and Pinus sylvestris after fractioning into different particle sizes," Industrial Crops and Products 36(1), 395-400. DOI:

10.1016/j.indcrop.2011.10.035

Miranda, I., Gominho, J., Mirra, I., and Pereira, H. (2013). "Fractioning and chemical characterization of barks of Betula pendula and Eucalyptus globulus," Industrial Crops and Products 41, 299-305. DOI: 10.1016/j.indcrop.2012.04.024

Miyazaki, J., and Hirabayashi, Y. (2011). "Effect of the addition of Acacia mangium bark on thermosetting of phenol-formaldehyde resin," Wood Science and Technology 45(3), 449-460. DOI: 10.1007/s00226-010-0342-6

Molnár, S. (2004). Faanyagismeret (“Wood Science”), Mezőgazdasági Szaktudás kiadó, Budapest, Hungary.

Muñoz, F., Ballerini, A., and Gacitúa, W. (2013). "Variability of physical, morphological and thermal properties of Eucalyptus nitens bark fiber," Maderas Ciencia y Tecnología 15(1), 17-30. DOI: 10.4067/S0718-221X2013005000002

Muszynski, Z., and McNatt, J. D. (1984). "Investigations on the use of spruce bark in the manufacture of particleboard in Poland," Forest Products Journal 34(1), 28-35.

Nagy, G., Novák, Á., and Osztroluczky, M. (1998). Zöld szerkezetek (Green Constructions), Ybl Miklós Müszaki Főiskola, Multimédia Laboratórium, Kiadó, Budapest, Hungary.

Narasimhachari, N., and von Rudloff, E. (1961). "The chemical composition of the wood and bark extractives of Juniperus horisontalis Moench," Canadian Journal of Chemistry 39, 2572-2581. DOI: 10.1139/v61-339

Naunes, E., Qbuilhó, T., and Pereira, H. (1999). "Anatomy and chemical composition of Pinus pinea L. bark,” Annals of Forest Science 56(6), 479-484. DOI: 10.1051/forest:19990604

Navid, M. H., Laszczyk-Lauer, M. N., Reichling, J., and Schnitzler, P. (2014). "Pentacyclic triterpenes in birch bark extract inhibit early step of herpes simplex virus type 1 replication," Phytomedicine 21(11), 1273-1280. DOI: 10.1016/j.phymed.2014.06.007

Németh, K., and Molnár, S. (1983). “Az akácfa égésmelegének és fütőértékének vizsgálata" (“Investigation of fuel value of black locust”), Faipar 3.

Nemli, G., and Çolakoğlu, G. (2005). "Effects of mimosa bark usage on some properties of particleboard," Turkish Journal of Agriculture and Forestry, 29(3), 227-230.

NEURO CT Pécsi Diagnosztikai Központ Kft (2010). "Hatóanyagként kapszaicint és illóolajokat együttesen tartalmazó kozmetikai készítmény, eljárás előállítására és alkalmazása" ("Cosmetic product comprising capsaicin and essential oil as active agents, method for the production and use thereof') Hungary patent number P1,000,690. 
O'Hare, G. P. (1974). "Lichens and bark acidification as indicators of air pollution in west central Scotland," Journal of Biogeography 1(2), 135-146. DOI: $10.2307 / 3037960$

Obernberger, I., and Thek, G. (2004). "Physical characterisation and chemical composition of densified biomass fuels with regard to their combustion behaviour," Biomass and Bioenergy 27(6), 653-669. DOI: 10.1016/j.biombioe.2003.07.006

Olander, B., and Steenari, B. M. (1995). "Characterization of ashes from wood and straw," Biomass and Bioenergy 8(2), 105-115. DOI: 10.1016/0961-9534(95)00004-Q

Oramahi, H. A., and Diba, F. (2013). "Maximizing the production of liquid smoke from bark of Durio by studying its potential compounds," Procedia Environmental Sciences 17, 60-69. DOI: 10.1016/j.proenv.2013.02.012

Orlandi, L., Vilela, F. C., Santa-Cecília, F. V., Dias, D. F., Alves-da-Silva, G., and Giusti-Paiva, A. (2011). "Anti-inflammatory and antinociceptive effects of the stem bark of Byrsonima intermedia A. Juss," Journal of Ethnopharmacology 137(3), 14691476. DOI: 10.1016/j.jep.2011.08.032

Orlovskaya, T. V., Gyulbyakova, K. N., Guzhva, N. N., Ogurtsov, Y. A. (2013). "Studying the Tilia cordata L. bark with the purpose of creation the new medicines," Modern Problems of Science and Education 2, 4-27.

Oskolski, A. A., and Van Wyk, B. E. (2010). "Wood and bark anatomy of Centella: Scalariform perforation plates support an affinity with the subfamily Mackinlayoideae (Apiaceae)," Plant Systematics and Evolution 289(3), 127-135. DOI: $10.1007 / \mathrm{s} 00606-010-0338-6$

Östlund, L., Ahlberg, L., Zackrisson, O., Bergman, I., and Arno, S. (2009). “Barkpeeling, food stress and tree spirits - The use of pine inner bark for food in Scandinavia and North America," Journal of Ethnobiology 29(1), 94-112. DOI: 10.2993/0278-0771-29.1.94

Palma, G., Freer, J., and Baeza, J. (2003). "Removal of metal ions by modified Pinus radiata bark and tannins from water solutions," Water Research 37, 4974-4980. DOI: 10.1016/j.watres.2003.08.008

Patnukao, P., and Pavasant, P. (2008). "Activated carbon from Eucalyptus camaldulensis Dehn bark using phosphoric acid activation," Bioresource Technology 99(17), 85408543. DOI: 10.1016/j.biortech.2006.10.049

Pecznik, P., and Körmendi, P. (szerk.) (2002). Hőenergia Gazdálkodás- biomassza Tüzelés ("Thermal energy management and biomass burning"), FM Müszaki Int. 1997, Gödöllö, Hungary.

Pedieu, R., Riedl, B., and Pichette, A. (2008a). "Properties of white birch (Betula papyrifera) outer bark particleboards with reinforcement of coarse wood particles in the core layer," Annals of Forest Science 65(7), 701. DOI: 10.1051/forest:2008053

Pedieu, R., Riedl, B., and Pichette, A. (2008b). "Physical and mechanical properties of panel based on outer bark of white birch: mixed panels with wood particles versus wood fibres," Maderas Ciencia y Tecnología 10(3), 195-206. DOI: 10.4067/S0718221X2008000300003

Pedieu, R., Riedl, B., and Pichette, A. (2009). "Properties of mixed particleboards based on white birch (Betula papyrifera) inner bark particles and reinforced with wood fibres," European Journal of Wood and Wood Products 67(1), 95-101. DOI: 10.1007/s00107-008-0297-6

Pinto, P. C. R. O., Sousa, A. F., Silvestre, A. J. D., Neto, C. P., Gandini, A., Eckerman, C., and Holmbom, B. (2009). "Quercus suber and Betula pendula outer barks as 
renewable sources of oleochemicals: A comparative study," Industrial Crops and Products 29(1), 126-132. DOI: 10.1016/j.indcrop.2008.04.015

Piotrowska, P., Skoglund, N., Grimm, A., Boman, C., Öhman, M., Zevenhoven, M., Boström, D., and Hupa, M. (2012). "Systematic studies of ash composition during the co-combustion of rapeseed cake and bark," in: Proceedings of the 21st International Conference on Fluidized Bed Combustion, Naples, Italy.

Poikolainen, J. (1997). "Sulphur and heavy metal concentrations in Scots pine bark in northern Finland and the Kola Peninsula," Water, Air, and Soil Pollution 93(1), 395408. DOI: $10.1007 / \mathrm{BF} 02404769$

Polubojarinov, O.I., 1976. Density of Wood. Nauka Publ., Moskow, p. 159 (in Russian)

Polubojarinov, O. J. (1976). Plotnoszty dreveszini ("Density of the wood"), Leszneja pramislenoszty, Moscow Russia.

Ponomarenko, J., Trouillas, P., Martin, N., Dizhbite, T., Krasilnikova, J., and Telysheva, G. (2014). "Elucidation of antioxidant properties of wood bark derived saturated diarylheptanoids: A comprehensive (DFT-supported) understanding," Phytochemistry 103, 178-187. DOI: 10.1016/j.phytochem.2014.03.010

Popp, M. P., Johnson, J. D., and Massey, T. L. (1991). "Stimulation of resin flow in slash and loblolly pine by bark beetle vectored fungi," Canadian Journal of Forest Research 21(7), 1124-1126. DOI: 10.1139/x91-155

Pollard, M., Beisson, F., Li Y., and Ohlrogge J. B. (2008). "Building lipid barriers: Biosynthesis of cutin and suberin," Trends in Plant Science 13(5), 236-246. DOI:10.1016/j.tplants.2008.03.003

Portik, K. I. (2006). “A fenyő hasznosítása a Székelyföldön” (“Utilization of coniferous in Transylvania”), Székelyföld- kulturális folyóirat 10(12).

Poyraz, M. U., and Mat, A. (2014). "The miracle bark Chinhona and malaria in the Ottoman Empire," in: National Conference on the History of Turkish Pharmacy, Lokman Hekim Journal, Kayseri, Turkey, p. 60.

Ragland, K. W., and Aerts, D. J. (1991). "Properties of wood for combustion analysis," Bioresource Technology 37(2), 161-168. DOI: 10.1016/0960-8524(91)90205-X

Randall, J. M., Hautala, E., Waiss, C. A., and Tschernitz, J. L. (1976). "Modified barks as scavengers for heavy metal ions," Forest Products Journal 26, 46-50.

Rápóti, J., and Romváry, V. (1997). Gyógyító Növények (“Healing plants”), Medicina Könyvkiadó Rt, Budapest, Hungary.

Raymund, R. (1940). "A fakéreg” (“The treebark”), A Természet 36(1), 2-5.

Ressel, J. B. (2006). "Wood yard operations," in: Handbook of Pulp, H. Sixta (ed.), WILEY-VCH Verlag GmbH \& Co. KGaA, Weinheim, Germany. DOI: 10.1002/9783527619887.ch3

Robertson, L. (2014). "Rethinking material culture: Ugandan bark cloth," in: Textile Society of America Symposium Proceedings, 14th Biennial Symposium, Los Angeles, CA, USA.

Rowe, J. W., Bower, C. L., and Wagner, E. R. (1969). "Extractives of jack pine bark: Occurrence of cis- and trans-pinosylvin dimethyl ether and ferulic acid esters," Phytochemistry 8(1), 235-241. DOI: 10.1016/S0031-9422(00)85819-7

Rudenko, B. D. (2010). "Influence of structure on formation of properties of plates from the bark and secondary polyethylene," Moscow State Forest University Bulletin Lesnoy Vestnik 4, 151-154.

Saarela, K. E., Harju, L., Rajander, J., Lill, J. O., Heselius, S. J., Lindroos, A., and Mattsson, K. (2005). "Elemental analyses of pine bark and wood in an environmental 
study," Science of The Total Environment 343(1-3), 231-241. DOI:

10.1016/j.scitotenv.2004.09.043

Saayman, H. M., and Oatley, J. A. (1976). "Wood adhesives from wattle bark extract," Forest Products Journal 26(11-12), 27-33.

Salem, N. M., and Awwad, A. M. (2014). "Biosorption of Ni(II) from electroplating wastewater by modified (Eriobotrya japonica) loquat bark," Journal of Saudi Chemical Society 18(5), 379-386. DOI: 10.1016/j.jscs.2011.07.008

Santamaría, J. M., and Martin, A. (1997). "Tree bark as a bioindicator of air pollution in Navarra, Spain," Water, Air, and Soil Pollution 98(3), 381-387. DOI: 10.1007/BF02047045

Santos, E. N., Lima, J. C. S., Noldin, V. F., Cechinel-Filho, V., Rao, V. S. N, Lima, E. F., Schmeda-Hirschmann, G., Sousa, Jr., P. T., and Martins, D. T. O. (2011). "Antiinflammatory, antinociceptive, and antipyretic effects of methanol extract of Cariniana rubra stem bark in animal models," Anais da Academia Brasileira de Ciencias 83(2), 557-566. DOI: 10.1590/S0001-37652011005000006

Santos, S. A. O., Pinto, P. C. R. O., Silvestre, A. J. D., and Neto, C. P. (2010). "Chemical composition and antioxidant activity of phenolic extracts of cork from Quercus suber L.," Industrial Crops and Products 31(3), 521-526. DOI: 10.1016/j.indcrop.2010.02.001

Sári, J. Sz. (2008). "Tőzeghelyettesítő anyagok a paprikahajtatásban (Peat substitute materials in green pepper production)," Doctoral thesis, Budapesti Corvinus Egyetem (Talajtan és Vízgazdálkodási Tanszék), Budapest, Hungary.

Sarkar, R., Chaudhary, S. K., Sharma, A., Yadav, K. K., Nema, N. K., Sekhoacha, M., Karmakar, S., Braga, F. C., Matsabisa, M. G., Mukherjee, P. K., and Sen, T. (2014). "Anti-biofilm activity of Marula - A study with the standardized bark extract," Journal of Ethnopharmacology 154(1), 170-175. DOI: 10.1016/j.jep.2014.03.067

Satake, K., Tanaka, A., and Kimura, K. (1996). "Accumulation of lead in tree trunk bark pockets as pollution time capsules," The Science of the Total Environment 181(1), 2530. DOI: 10.1016/0048-9697(95)04955-X

Sato, Y., Konishi, T., and Takahashi, A. (2004). "Development of insulation material using natural tree bark," Transactions of the Materials Research Society of Japan 29(5), 1937-1940.

Sawidis, T., Breuste, J., Mitrovic, M., Pavlovic, P., and Tsigaridas, K. (2011). "Trees as bioindicator of heavy metal pollution in three European cities," Environmental Pollution 159, 3560-3570. DOI: 10.1016/j.envpol.2011.08.008

Schafer, J. L., Breslow, B. P., Hohmann, M. G., and Hoffmann, W. A. (2015). "Relative bark thickness is correlated with tree species distribution along a fire frequency gradient," Fire Ecology 11(1), 74-87. DOI: 10.4996/fireecology.1101074

Schneider, A., and Baums, A. (1970). Wohin mit der Rinde? DRW-Verlag GmbH, Stuttgart, Germany, $52 \mathrm{pp}$.

Schulz, H., Popp, P., Huhn, G., Stärk, H. J., and Schürmann, G. (2000a). "Biomonitoring of airborne inorganic and organic pollutants by means of pine tree barks. - I. Temporal and spatial variations," in: Biomonitoring of Atmospheric Pollution (with Emphasis on Trace Elements) - BioMAP (IAEA-TECDOC-1152), B. Smodis (ed.), International Atomic Energy Agency, Vienna, Austria, pp. 149-158. DOI: 10.1016/S0048-9697(99)00109-6

Schulz, H., Schulz, U., Huhn, G., and Schürmann G. (2000b). "Biomonitoring of airborne inorganic and organic pollutants by means of pine tree barks. - II. Deposition types 
and impact levels," in: Biomonitoring of Atmospheric Pollution (with Emphasis on Trace Elements) - BioMAP (IAEA-TECDOC-1152), B. Smodis (ed.), International Atomic Energy Agency, Vienna, Austria, pp. 159-167.

Schweizer, G. (1975). "Versuche zur Optimierung der Schlammentwässerung und zur Verwertung von Rinde und Schlamm in der Ziegelindustrie," Wochenblatt für Papierfabrikation 22, 833-839.

Schweizer, G., and Meigel, P. (1977). "Über die Verwertung von Entrindungsabfall als Porosierungsstoff in der Ziegelindustrie," Das Papier 10A, V27-V32.

Semenovich, A. V., Loskutov, S. R., Permyakova, G. V. (2008). "Collection of oil spills by modified bark of coniferous," Chemistry of Plant Raw Material 2, 113-118.

Semenovich, A. V., Loskutov, S. R. (2015). "The bark of coniferous trees is a promising raw material for the manufacture of various sorbents," Biotechnology and Society in the XXI Century, 269-272.

Şen, A., Isabel Miranda, I., Santos, S., Graça, J., and Pereira, H. (2010). “The chemical composition of cork and phloem in the rhytidome of Quercus cerris bark," Industrial Crops and Products 31(2), 417-422. DOI: 10.1016/j.indcrop.2010.01.002

Şen, A., Quilhó, T., and Pereira, H. (2011). "The cellular structure of cork from Quercus cerris var. cerris bark in a materials' perspective," Industrial Crops and Products 34(1), 929-936. DOI: 10.1016/j.indcrop.2011.02.015

Şensöz, S. (2003). "Slow pyrolysis of wood barks from Pinus brutia Ten. and product compositions," Bioresource Technology 89(3), 307-311. DOI: 10.1016/S09608524(03)00059-2

Shin, S. J., and Han, S. H. (2014). "Investigation of solid energy potential of wood and bark obtained from four clones of a two-year old goat willow," Frontiers in Energy Research 2(5). DOI: 10.3389/fenrg.2014.00005

Sopp, L., and Kolozs, L. (2000). "Fatömegszámítási táblázatok" ("Cubage tables of trees”), Állami Erdészeti Szolgálat, Budapest, Hungary, pp. 24-29.

Starecki, A. (1979). "Spanplatten aus Holz mit Rindenanteil," Holztechnologie 20(2), 108-111.

Staxäng, B. (1969). “Acidification of bark of some deciduous trees," Oikos 20(2), 224230. DOI: $10.2307 / 3543190$

Stayton, C. L., Hyvarinen, C. M., Gertjejansen, R. O., and Haygreen, J. G. (1971). "Aspen and paper birch mixtures as raw material for particleboard," Forest Products Journal 21(12), 29-30.

Steindor, K., Palowski, B., Góras, P., and Nadgórska-Socha, A. (2011). "Assessment of bark reaction of select tree species as an indicator of acid gaseous pollution," Polish Journal of Environment Studies 20(3), 619-622.

Sudakova, I. G., Garyntseva, N. V., Ivanov, I. P., Kuznetsov, B. N. (2012). "Isolation and application of suberin from outer birch-bark," Journal of Siberian Federal University, Chemistry, 5(2), 168-177.

Sudakova, I. G., Ivanov, I. P., Ivanchenko N. M., Kuznetsov, B. N. (2005). "Protective compositions for wood on the basis of the suberin of birch bark," Chemistry of Plant Raw Material 1, 59-63.

Suzuki, K. (2006). "Characterization of airborne particulates and associated trace metals deposited on tree bark by ICP-OES, ICP-MS, SEM-EDX and laser ablation ICP-MS," Atmospheric Environment 40(14), 2626-2634. DOI: 10.1016/j.atmosenv.2005.12.022 
Świeboda, M., and Kalemba, A. (1979). "The bark of Scots pine (Pinus sylvestris L.) as a biological indicator of atmospheric air pollution," Acta Societatis Botanicorum Poloniae 48(4), 539-549. DOI: 10.5586/asbp.1979.045

Szalay, L. (1981). A fahulladék hasznosítása ("Utilization of wood waste"), Múszaki Könyvkiadó, Budapest, Hungary.

Szatyor, Gy. (1986). Famüvesség ("Wood skills”), Mezőgazdasági Kiadó, Budapest, Hungary.

Szendrey, I. (1986). Faipari kémiai technológia 1 ("Wood chemistry"), Egyetemi Jegyzet, Sopron, Hungary.

Terangpi, R., Basumatary, R., Tamuli, A. K., and Teron, R. (2013). "Pharmacognostic and physicochemical evaluation of stem bark of Acacia pennata (L.) willd., a folk plant of the Dimasa tribe of Assam," Journal of Pharmacognosy and Phytochemistry 2(2), 134-140.

Thalhamer, B., and Himmelsbach, M. (2014). "Characterization of quillaja bark extracts and evaluation of their purity using liquid chromatography-high resolution mass spectrometry," Phytochemistry Letters 8, 97-100. DOI: 10.1016/j.phytol.2014.02.009

Tóth, L. (2005). "Gyógynövények, drogok, fitoterápia" (“Herbs, drugs and fitoteraphy"), Kossuth Egyetemi Kiadó, Debrecen, Hungary.

Ugolev, B. N. (1986). “Древесиноведение с основами лесного товароведения” ("Wood science with the basics of forest products"), $2^{\text {nd }}$ Revised Edition, Lesnaja promyshlennost, Moscow, Russia.

Ushanova, V. M. (2012). Complex Processing of Siberian Fir Needles and Barkfor Obtaining Products Having Biological Activity, Ph.D. dissertation, Siberian State Technological University, Krasnoyarsk, Russia

Usta, M., and Kara, Z. (1997). "The chemical composition of wood and bark of Cedrus libani A. Rich," Holz als Roh- und Werkstoff 55(2), 268. DOI: 10.1007/BF02990561

Vajda, B. (2006). "Parafa az építőiparban (Cork in the building industry)," (http://fenntarthato.hu/).

Vajda, M. (2002). “Kezelt fakéreg lipidek eltávolítására vízbool (Treated tree bark for removal of lipids from water)," Környezetvédelem- információs folyóirat, BMEOMIKK 17-18, 61-70.

Valentín, L., Kluczek-Turpeinen, B., Willför, S., Hemming, J., Hatakka, A., Steffen, K., and Tuomela, M. (2010). "Scots pine (Pinus sylvestris) bark composition and degradation by fungi: Potential substrate for bioremediation," Bioresource Technology 101(7), 2203-2209. DOI: 10.1016/j.biortech.2009.11.052

Vasconcelos, C. F. B., Maranhão, H. M. L., Batista, T. M., Carneiro, E. M., Ferreira, F., Costa, J., Soares, L. A. L., Sá, M. D. C., Souza, T. P., and Wanderley, A. G. (2011). "Hypoglycaemic activity and molecular mechanisms of Caesalpinia ferrea Martius bark extract on streptozotocin-induced diabetes in Wistar rats," Journal of Ethnopharmacology 137(3), 1533-1541. DOI: 10.1016/j.jep.2011.08.059

Vázquez, G., Fontenla, E., Santos, J., Freire, M. S., González-Álvarez, J., and Antorrena, G. (2008). "Antioxidant activity and phenolic content of chestnut (Castanea sativa) shell and eucalyptus (Eucalyptus globulus) bark extracts," Industrial Crops and Products 28(3), 279-285. DOI: 10.1016/j.indcrop.2008.03.003

Venkatesan, T., Choi, Y. W., and Kim, Y. K. (2015). "The cytotoxic nature of Acanthopanax sessiliflorus stem bark extracts in human breast cancer cells," Saudi Journal of Biological Sciences 22(6), 752-759. DOI: 10.1016/j.sjbs.2015.04.004 
Venter, P. B., Senekal, N. D., Kemp, G., Amra-Jordaan, M., Khan, P., Bonnet, S. L., and van der Westhuizen, J. H. (2012). "Analysis of commercial proanthocyanidins. Part 3: The chemical composition of wattle (Acacia mearnsii) bark extract," Phytochemistry 83, 153-167. DOI: 10.1016/j.phytochem.2012.07.012

Verkerk, P. J., Anttila, P., Eggers, J., Lindner, M., and Asikainen, A. (2011). “The realisable potential supply of woody biomass from forests in the European Union," Forest Ecology and Management 261(11), 2007-2015. DOI: 10.1016/j.foreco.2011.02.027

Wang, G. G., and Wangen, S. R. (2011). "Does frequent burning affect longleaf pine (Pinus palustris) bark thickness?" Canadian Journal of Forest Research 41(7), 15621565. DOI: $10.1139 / \mathrm{x} 11-074$

Wang, L., and Dibdiakova, J. (2014). "Characterization of ashes from different wood parts of Norway spruce tree," Chemical Engineering Transactions 37, 37-42. DOI: 10.3303/CET1437007.

Wang, Q., Zhu, C., Wang, Y., Huang, Z., Li, Z., and Huang, B. (2003). “A novel sampling method for present and historical monitoring of air pollution by using tree bark," Environmental Chemistry 22(3), 250-254

Weissmann, G. (1976). "Reinung Ölhaltiger Abwässer mit Rinde,” Holz-Zentralblatt 50, 661-662.

Whiting, D., Wilson, C., Moravec, C., and Reeder, J. (2015). Mulching with Wood/Bark Chips, Grass Clippings, and Rock, Colorado Master Gardeners Program, Yard and Garden Publications, Colorado State University Extension, Ft. Collins, CO, USA.

Winkler, A. (1978). A fakéreg struktúrájának és megfelelö fizikai- mechanikai tulajdonságú fakéreglapok gyárthatóságának kapcsolata (Connection of Tree Bark Structure and Mechanical and Physical Properties of Board Production), Ph.D. dissertation, University of Forest and Wood Science, Sopron, Hungary.

Yang, P., and Jenkins, B. M. (2008). "Wood residues from sawmills in California," Biomass and Bioenergy 32(2), 101-108. DOI: 10.1016/j.biombioe.2007.09.001

Yemele, M. C. N., Koubaa, A., Cloutier, A., Soulounganga, P., and Wolcott, M. (2010). "Effect of bark fiber content and size on the mechanical properties of bark/HDPE composites, Composites Part A," Applied Science and Manufacturing 41(1), 131-137. DOI: 10.1016/j.compositesa.2009.06.005

Young, C. (1937). "Acidity and moisture in tree bark," Proceedings of the Indiana Academy of Science 47, 106-114.

Young, H. E. (1971). "Preliminary estimates of bark percentages and chemical elements in complete trees of eight species in Maine," Aspen Bibliography 21(5), 56-59.

Zhang, L., Chen, J., Wang, Y., Wu, D., and Xu, M. (2010). "Phenolic extracts from Acacia mangium bark and their antioxidant activities," Molecules 15(5), 3567-3577. DOI: $10.3390 /$ molecules15053567

Zhitkov, A. V. (1985). Utilization of Wood Bark, Lesnaja Promyshlennost, Moscow, Russia.

Zsindelyes Kereskedőház Kft (2011). "Likőr és előállítása (Liqueur and process for production thereof)," Hungary patent number P1100094/6.

Article submitted: February 27, 2016; Peer review completed: May 9, 2016; Revised version received and accepted; May 10, 2016; Published: May 24, 2016.

DOI: 10.15376/biores.11.3.Pasztory 